Comparison of estradiol benzoate doses at beginning of the synchronization and early resynchronization of ovulation for timedinsemination in Bos indicus beef cows.

Pirassununga

2021 
Comparison of estradiol benzoate doses at beginning of the synchronization and early resynchronization of ovulation for timedinsemination in Bos indicus beef cows.

Dissertation submitted to the Postgraduate Program in Animal Reproduction of the School of Veterinary Nitedicine and Animal Science of the University of São Paulo to obtain the Master's degree Prseiences.

Department:

Animal Reproduction

Area:

Animal Reproduction

Advisor:

Prof. Guilherme Pugliesi, Ph.D. 
Total or partial reproduction of this work is permitted for academic purposes with the proper attribution of authorship and ownership of the rights.

DADOS INTERNACIONAIS DE CATALOGAÇÃO NA PUBLICAÇÃO

(Biblioteca Virginie Buff D’Ápice da Faculdade de Medicina Veterinária e Zootecnia da Universidade de São Paulo)

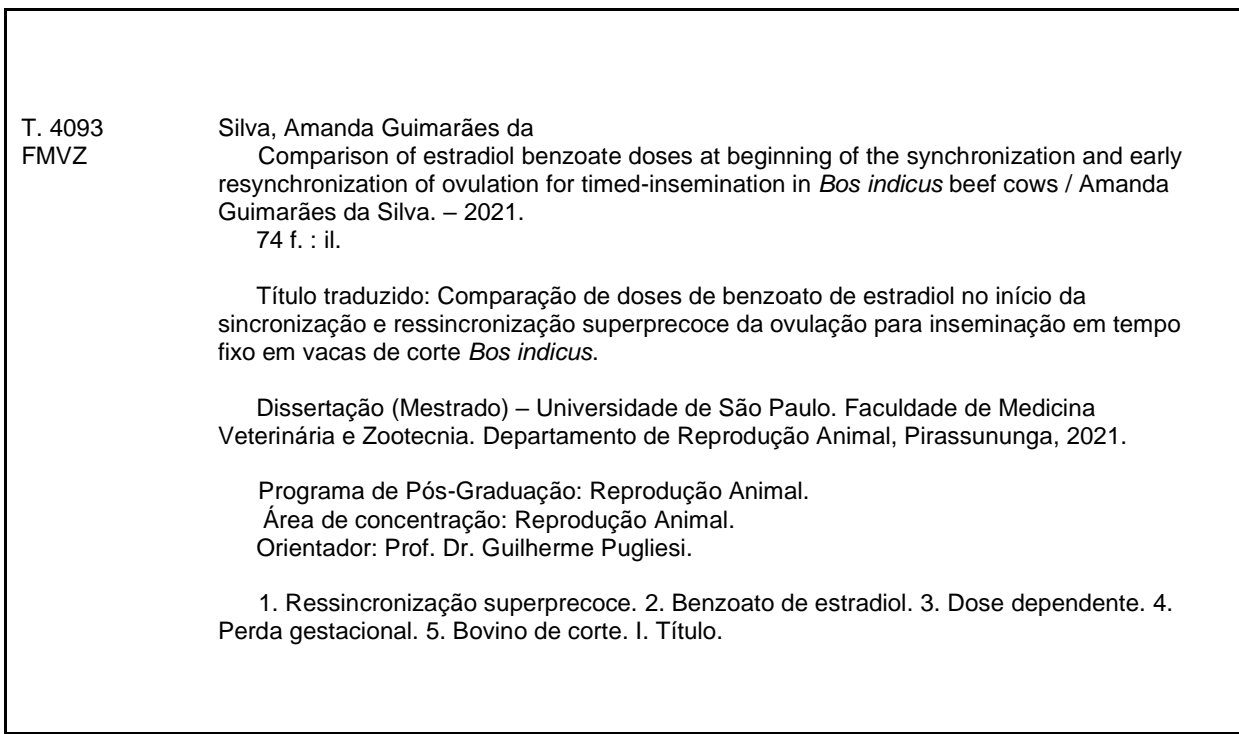

Ficha catalográfica elaborada pela bibliotecária Maria Aparecida Laet, CRB 5673-8, da FMVZ/USP. 


\section{Comissão de Ética no Uso de Animais}

Faculdade de Medicina Veterinária e Zootecnia

Universidade de Sao Paulo

\section{CERTIFICADO}

Certificamos que a proposta intitulada "Uso de diferentes doses de benzoato de estradiol na sincronização e ressincronização aos 14 dias após a IATF em vacas de corte Bos indicus", protocolada sob o CEUA n 3851080519 (10 $005750 \%$, 50b a responsabilidade de Guilherme Pugliesi e equipe: Amanda Guimarāes da Silva - que envolve a produçāo, manutençāo e/ou utilizaçāo de animais pertencentes ao filo Chordata, subfilo Vertebrata (exceto o homem). para fins de pesquisa científica ou ensino - está de acordo com os preceitos da Lei 11.794 de 8 de outubro de 2008, com o Decreto 6.899 de 15 de julho de 2009, bem como com as normas editadas pelo Conselho Nacional de Controle da Experimentaçāo Animal (CONCEA), e foi aprovada pela Comissāo de Ética no Uso de Animais da Faculdade de Medicina Veterinária e Zootecnia da Universidade de Sāo Paulo (CEUA/FMVZ) na reuniāo de $02 / 07 / 2019$.

We certify that the proposal "Use of different doses of estradiol benzoate in synchronization and resynchronization at 14 days after FTAl in beef cows Bos indicus", utilizing 1750 Bovines (1750 females), protocol number CEUA 3851080519 iD o0675a), under the responsibility of Guilherme Pugliesi and team; Amanda Guimarāes da Silva - which involves the production, maintenance and/or use of animals belonging to the phylum Chordata, subphylum Vertebrata (except human beings). for scientific research purposes or teaching - is in accordance with Law 11.794 of October 8, 2008, Decree 6899 of July 15, 2009, as well as with the rules issued by the National Council for Control of Animal Experimentation (CONCEA), and was approved by the Ethic Committee on Animal Use of the School of Veterinary Medicine and Animal Science (University of São Paulo) (CEUA/FMVZ) in the meeting of 07/02/2019.

Finalidade da Proposta: Pesquisa

Vigência da Proposta: de 06/2019 a 05/2020

Area: Reprodução Animal

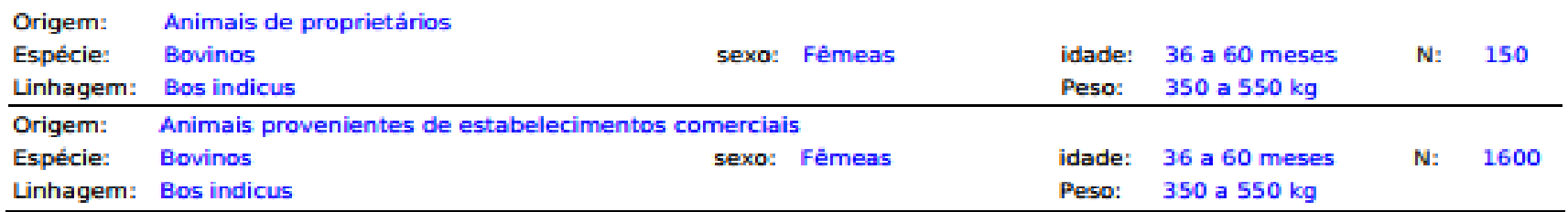

Local do experimento: Os experimentos de dinâmica folicular e dinámica luteal serão realizados nas dependências do Departamento de Reprodução Animal da Universidade de São Paulo, no Campus de Pirassununga e na Unidade Experimental Apta Tietê. Já o protocolo de ressincronização, sem acompanhamento da dinâmica luteal, será realizado em uma fazenda comercial voltada para a pecuária de corte.

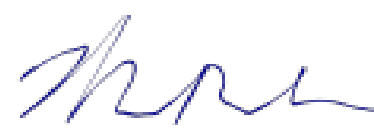

Prof. Dr. Marcelo Bahia Labruna

Coordenador da Comissão de Ética no Uso de Animais Faculdade de Medicina Veterinária e Zootecnia da Universidade de São Paulo

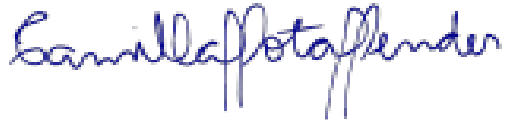

Camilla Mota Mendes

Vice-Coordenadora da Comissāo de Etica no Uso de Animais Faculdade de Medicina Veterinária e Zootecnia da Universidade de São Paulo 


\section{EVALUATION FORM}

Author: SILVA, Amanda Guimarães

Title: Comparison of estradiol benzoate doses at beginning of the synchronization and early resynchronization of ovulation for timedinsemination in Bos indicus beef cows.

Dissertation submitted to the Postgraduate Program in Animal Reproduction of the School of Veterinary Medicine and Animal Science of the University of São Paulo to obtain the Master's degree in Sciences.

Date:

\section{Committee Members}

Prof.

Institution: Decision:

Prof.

Institution: Decision:

Prof.

Institution: Decision: 
I dedicate this dissertation to the most important persons of my life, my mother Zuneide and my sister Carla, whose your love, dedication, encouragement and support made me able to get here. To you, all my love. 


\section{ACKNOWLEDGEMENTS}

I would like to thank God for enlightening me all my way. I would also like to thank him for being the daughter and sister of who I am. Thank you God for putting in my life two strong women who did not allow any difficulty to interrupt the dream of a girl who dreamed of studying Veterinary Medicine.

To my mother, Zuneide Guimarães, all my love and gratitude for having made my dreams hers. Thank you for being my greatest regret at every farewell and my safe haven at every arrival. My sister, Carla Castro, who always made me a priority in her life. I couldn't have a better big sister/younger mother than you. Thank you for sharing this arduous mission with Mom. This achievement is more yours than mine and I continue to say, you are the reason for many more achievements to come. Let's go together, always! I love you to the moon and back.

I am grateful to my grandmother, Maria de Lourdes, who has always been so proud of having a granddaughter who is a Veterinarian; and to my dear friend and grandfather, Zueber Coetho (in memorian), who,

since I was little, took part in the rescue of stray animals and inflated this desire to become a Veterinarian. Grandpa, I know that since you left I have gained another angel looking down on me. Thank you for being present at each achievement! I love you with all my heart.

Thanks to my cousin-sisters, Larissa and Lorena. My aunt Rita for her support over the years. To my dear uncle Manoel (in memorian) who left us so early but who always wanted to know the news of adult life 
and always had a word he knew for me. To my cousin André for the encouragement and affection in every conversation. Thank you for being more than a bond of blood, for being a bond of love. This love will only overflow every day with Alicinha brightening our lives.

And speaking of bonds of love, there are 7 girls (today women) that I have a lot to be thankfulfor. They have been my friends since school. How long ago, Amanda? I do not know. I just look back and see no good/bad times that they aren't. Bárbara Mattos, Elis Fontes, Karoline Freitas, Letícia Botelho, Mariana Hage and Thainá Fraga, thank you for being my most beautiful example of friendship. Thank you for sharing so many phases of our lives. Thank you for even after a few months of not meeting making it look like we were together yesterday at the school playground (with a few more responsibilities, more slips and most importantly, more achievements). I love you so much.

Thanks to my friends Thomas Salles, Ligia Oliveira, Luisa Crivelli, Tatiana Assis and Ana Paula Shmidt, Marcus Vinicius and Pedro Vital, gifts that VetUfF gave me. Thank you to my dear friend Fernanda, who, even from afar, was always so present.

I thank my dear friends Lilian Góes and Rodrigo Jardim for all their hospitality and affection during their time at the Bodoquena farm. Thanks for everything, my friends!!! 
Thanks to the dear friends I made in RepHour Republic, my first house in Pirassununga: María Laura (Yeti), Ana Luiza (Moita), Carol (Kerol), Nathália (Miamarra), Letícia (Smeg), Giovana (Chiclete), Fernanda ( Fer), Rafaela (Garfíeld), Isabela Rodrigues (Risoto), Maria Clara (Olaf) and Leticia (Rabiola). Thanks for all the welcome, girls.

Thanks so much to my advisor, Guilherme Pugliesi, with whom I have been constantly learning, since I started a technical training in 2018. Thank you for all the opportunities and for all your patience in explaining the same thing several times. All the questions and "convince me", "it has to be consistent" were key. Thanks also for the moments of relaxation, sending photos from the laboratory camera at 8:oo pm telling us not to get discouraged with the ELISA.

My thanks to this (dream) team, in which I made great friends:

Thanks to my Cecilia for all the help inside and outside the laboratory. you are an inspiration, friend. Thanks for everything!

$\mathcal{M} y$ thanks to my dear friend and roommate Gilmar (who abandoned me). You have a giant heart, my friend. Thanks for the ideas of the numerous experiments we thought of doing. Thank you for the laughs (of despair sometimes) and also for the cries shared in times of tension.

My thanks to Igor and Thiago for all their help with the field experiment. For making the days more fun, even when they laughed at my shampoo lying in the toilet, or when I was washing dishes they made me mad (soon it was over, I survived hahahaha). 
Thanks to Danilo and Diego, for their help with the ELISA plates, with the master's experiments and especially for playing the most bizarre pearls in the lab.

Thanks to Gabi Bruni for the help in the experiments and for the partnership we had in our season in Mato Grosso do Sul. On the trip you thanked me and there at the farm, I started to thank you every day for sharing this experience with you. Every success for you, friend.

Thanks to Leonardo, Pablo, Adomar and Priscila for all the help in carrying out the experiments.

Many thanks to the interns, students of technical training and professional practice who helped with both the ELISA and the master's experiments.

$\mathcal{M}$ y deepest thanks to my dear friends at home and in the lab Isabella Feltrin, Karine Morelli, Ana Degan, Thais Sayuri, and Ana Carolina Pedrosa for all the companionship, food, and endless conversations. you make the routine lighter and the laugh safer. Thanks for all the words said to calm me down, all the support and affection especially in difficult times.

I also thank the temporary members of fit 14, Lais Abreu, Luana Factor, Mariângela, Taynara, and Yasmin. Thanks for coming to add. Apartment 14 (also known as the mother's heart) has its doors open waiting for you. 
I thank dear friends and members of other VRA teams Sâmara Costa, Felipe Antoniolli (Gangorra), and Leonardo Batissaco (Bat) thank you for every conversation we had, help with statistics (right, Bati), each company for the "Gandejão", every laugh outside the study room.

Thanks to qualifying panel members $\mathcal{D} r$. $\mathcal{E} d \mathcal{H}$ foffman and $\mathcal{D} r$. Manoel Sá Filho for all the suggestions on the experimental design.

Thank you to $\mathcal{D}$ r. Roberto Sartori for your contribution to the qualifying panel and for returning to the master's defense panel, once again making your time available to read our work.

$\mathcal{M}$ y thanks to $\mathcal{D}$ r. Leticia Zoccolaro, whom I greatly admire. Thank you for all the encouragement, confidence and for now being part of this very important moment.

All my thanks to $\mathcal{D} r$. Rafael Herrera and $\mathcal{D}$ r. Keila Roncato for enabling our preliminary experiment in $\mathcal{A} \mathcal{P} \mathcal{T} \mathcal{A}$. Thanks to Diego for his help with the management of the animals.

Thanks to Marcio, José Maria and João for their help with the

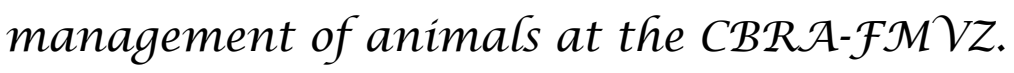

Many thanks to João Paulo Massoneto and Luiz Antonio Scandiuzzi for making it possible to carry out the resynchronization experiment at Agropecuária Água Preta. Many thanks to Raphael Orlandi (Fera Graaaba), Ronaldo, Elton and Leandro Inague from Reproduz 
Assessoria Pecuária team for providing the animals' bookkeeping and support in the management of the animals.

$\mathcal{A}$ lso, many thanks to all $\mathcal{V} \mathcal{R} \mathcal{A}$ professors, who are the responsible for making the postgraduate program in animal reproduction one of the best in the country

I thank Harumi and Clayton for their availability to clarify doubts and help during the master's degree.

I would like to thank the University of São Paulo and the Department of Animal Reproduction (VRA) for the incredible infrastructure and professionals, which allowed me to conduct my research.

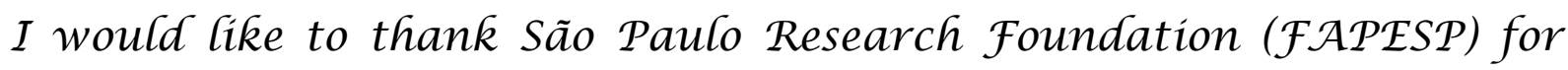
funding the project for financial support (Grant numbers 2015/10606-9 and 2019/07805-0) and Coordination for the Improvement of Higher Education Personnel (CAPPS). 
All my thanks to everyone who somehow contributed to me getting this far! 
"Sometimes we feel that what we do is just a drop of water in the sea. But the sea would be smaller if it lacked a drop". 


\section{RESUMO}

SILVA, A. G. Comparação de doses de benzoato de estradiol no início da sincronização e ressincronização superprecoce da ovulação para inseminação em tempo fixo em vacas de corte Bos indicus. 2021. 74 p. Dissertação (Mestrado em Ciências) - Faculdade de Medicina Veterinária e Zootecnia, Universidade de São Paulo, Pirassununga, 2021.

Com base no amplo uso de benzoato de estradiol (BE) em protocolos de IA em tempo fixo (IATF), objetivou-se com a presente pesquisa comparar os efeitos de diferentes doses de BE na sincronização da ovulação e ressincronização aos 14 dias após IATF em vacas Nelore (Bos indicus) lactantes. Para isso, esta dissertação consiste em dois estudos. No primeiro estudo, comparamos três doses de BE (1 mg, $\mathrm{n}=20 ; 1,5 \mathrm{mg}, \mathrm{n}=15$; e $2 \mathrm{mg}, \mathrm{n}=21$ ) associadas a um dispositivo de progesterona (P4) no início de um protocolo de sincronização para IATF em vacas de corte primíparas $(n=20)$ e multíparas $(n=36)$. O momento e sincronia da emergência da onda folicular não diferiu $(P>0,05)$ entre as doses de BE. A emergência folicular ocorreu mais tarde $(P<0,05)$ em vacas primíparas comparadas às multíparas. Além disso, o diâmetro folicular das primíparas foi menor $(P<0,05)$ que nas vacas multíparas no D-2 e na IATF. Concluímos com este estudo que doses de 1 a $2 \mathrm{mg}$ de BE foram eficazes em promover a emergência da nova onda folicular. Além disso, o atraso na emergência folicular em vacas primíparas contribuiu para a redução do diâmetro folicular na IATF em comparação com vacas multíparas. No segundo estudo, comparamos o uso de 1 ou $2 \mathrm{mg}$ de BE associado a um dispositivo de P4 no início do protocolo de ressincronização aos 14 dias após a IATF (D0) em vacas de corte Bos indicus lactantes (1 mg; grupo BE-1, $n=516$; e 2 mg, grupo BE$2, n=510$ ). No $D 14$, junto com o início da ressincronização, foi possível avaliar a presença de corpo lúteo ativo em 933 vacas. Além disso, um subgrupo dessas vacas ( $n=18-19 /$ grupo) foi submetido a avaliações ultrassonográficas diárias do D14 ao D22 para localização e mensuração do diâmetro dos folículos antrais e área do corpo lúteo, e avaliação da perfusão sanguínea do corpo lúteo. No D22, todas as vacas foram submetidas a avaliações ultrassonográficas no modo Doppler colorido para detecção de luteólise. Vacas com luteólise detectada no D22 foram submetidas a IATF2 no D24. O diagnóstico de gestação convencional foi realizado 30-35 dias após primeira ou segunda IATF. A taxa de prenhez por inseminação (P/IA) da IATF1 
foi $21,4 \%$ maior $(P<0,05)$ no grupo $B E-1$ do que no grupo $B E-2$. A potencial perda embrionária entre $D 22$ e D30-35 foi $100 \%$ maior $(P<0,05)$ no grupo $B E-2$ que no grupo BE-1. A P/IA da IATF2 não diferiu $(P>0,1)$ entre os grupos. Assim, com taxas de prenhez satisfatórias na IATF1 e na IATF2, o grupo BE-1 teve uma maior P/IA acumulada após duas IATFs com intervalo de 24 dias que o grupo BE-2. Portanto, podemos concluir que $1 \mathrm{mg}$ de $\mathrm{BE}$ é a dose segura e recomendada para ser utilizada associada ao dispositivo de P4 nos protocolos de ressincronização iniciados aos 14 dias pós-IATF.

Palavras-chave: Ressincronização superprecoce. Benzoato de estradiol. Dose dependente. Perda gestacional. Bovino de corte. 


\begin{abstract}
SILVA, A. G. Comparison of estradiol benzoate doses at beginning of the synchronization and early resynchronization of ovulation for timedinsemination in Bos indicus beef cows. 2021. 74p. Dissertação (Mestrado em Ciências) - Faculdade de Medicina Veterinária e Zootecnia, Universidade de São Paulo, Pirassununga, 2021.
\end{abstract}

Based on the wide use of estradiol benzoate (EB) in timed-AI (TAI) protocols, with this research we aimed to compare the effect of different doses of $E B$ in synchronization of ovulation and resynchronization at 14 days after TAl in suckled Nelore beef cows. Therefore, this dissertation consists of two studies. In the first study we compared three EB doses ( $1 \mathrm{mg}, \mathrm{n}=20 ; 1.5 \mathrm{mg}, \mathrm{n}=15$; and $2 \mathrm{mg}, \mathrm{n}=21$ ) associated with a progesterone device (P4) at the beginning of a synchronization protocol for TAl in primiparous $(n=20)$ and multiparous $(n=36)$ beef cows. Follicular wave emergence (FWE) did not differ $(P>0.05)$ among treatment groups, as well as the other features. The FWE occurred later $(P<0.05)$ in primiparous cows than in multiparous cows. In addition, the follicular diameter of primiparous was smaller $(\mathrm{P}<$ 0.05 ) than multiparous cows at D -2 and TAI. We conclude with this study that doses from 1 to $2 \mathrm{mg}$ EB were efficient in promoting the emergence of the new follicular wave. Furthermore, we also concluded that the delay in follicular emergence in primiparous cows contributed to the reduced follicular diameter at TAI compared to multiparous cows. In the second study, we compared the use of 1 or $2 \mathrm{mg}$ EB associated with a P4 device at the beginning of the resynchronization protocol at 14 days post-TAl in suckled Bos indicus beef cows (1 mg; EB-1 group, $n=516$; and 2mg, EB-2 group, $n=510)$. On D14, along with the beginning of resynchronization, it was possible to assess the presence of an active corpus luteum in 933 cows. In addition, a subgroup of these cows ( $n=18-19$ /group) was submitted to daily ultrasound assessments from day 14 to 22 for localization and measurement of antral follicles and corpus luteum area, and assessment of corpus luteum perfusion. On D22, all cows were submitted to ultrasound evaluations in color Doppler mode to detect luteolysis. Cows with luteolysis detected on D22 were submitted to TAl2 on D24. The conventional diagnosis of pregnancy was performed 30-35 days after TAl1 or TAI2. 
The pregnancy per $\mathrm{Al}(\mathrm{P} / \mathrm{Al})$ from first TAl was $21,4 \%$ greater $(\mathrm{P}<0.05)$ in the $\mathrm{EB}-1$ group than in the EB-2 group. The potential embryonic loss between D22 and D3035 was doubled $(P<0.05)$ in the EB-2 group. The P/Al of the second TAl did not differ $(P>0.1)$ between groups. Thus, with satisfactory pregnancy rates in TAl 1 and TAI 2, the EB-1 group had a greater cumulative P/Al after two TAls with a 24-day interval than the EB-2 group. Therefore, we can conclude that $1 \mathrm{mg}$ EB is the safe and recommended dose to be used in association with the $\mathrm{P} 4$ device in resynchronization protocols started at 14 days after TAI.

Keywords: Early resynchronization. Estradiol benzoate. Dose dependent. Pregnancy loss. Beef cattle. 


\section{LIST OF FIGURES}

Figure 1 - Schematic diagram of the experimental design

Figure 2 - Individual values to day of follicular wave emergence in multiparous ( $\mathbf{\Lambda})$ and primiparous ( $(\circ)$ cows

Figure 3 - Schematic diagram of the experiment

Figure 4 - Proportion of cows (\%) with an active $\mathrm{CL}$ at beginning of resynchronization protocol (D14) and at Doppler ultrasonography (D22) and with an embryo on B-mode diagnosis (D30-35) after first TAI. .45

Figure 5 - Proportion (\%) of potential early embryonic loss (PEEL) from D14 to D22 and late embryonic loss (PLEL) from D22 to D30-35 between treatment groups .46

Figure 6 - P/AI 30-35 days after second TAI (\%) and cumulative P/AI [TAI 1 + TAI 2] (\%) in EB-1 and EB-2 groups.

Figure 7 - Individual values to day of follicular wave emergence (FWE) between EB-1 and EB-2 groups.

Figure 8 - Mean \pm SEM CL area $\left(\mathrm{cm}^{2}\right)$ and blood perfusion in beef cows submitted to a resynchronization of ovulation program 14 days after TAl. .51 


\section{LIST OF TABLES}

Table 1 - Follicular wave emergence (FWE), follicle growth rate, dominant follicle diameter at TAI of cows (multiparous and primiparous) treated with 1, 1.5, or $2 \mathrm{mg} \mathrm{EB}$ at the beginning of the TAI protocol. All values are expressed as mean \pm SEM or proportions

Table 2 - Effect of body condition score (BCS) on the proportion (\%) of cows with an active $\mathrm{CL}$ at days 14 and 22 after TAI, P/AI TAI, potential early embryonic loss, potential late embryonic loss, and cumulative P/AI [TAl $1+$ TAI 2].

Table 3 - Ovarian characteristics in non-pregnant cows resynchronized with 1 or 2 mg EB associated to a P4 device at 14 days post-TAI. .50 
INTRODUCTION ........................................................................22

2 CHAPTER 1: COMPARISON OF THREE DOSES OF ESTRADIOL BENZOATE FOR SYNCHRONIZATION OF FOLLICULAR WAVE EMERGENCE IN SUCKLED BOS INDICUS BEEF COWS................... 25

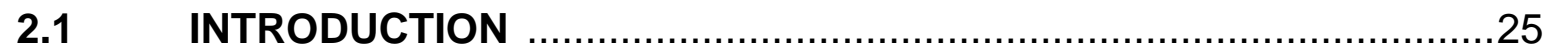



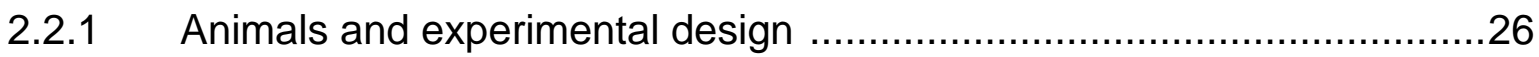

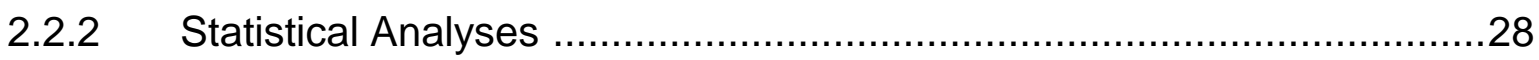

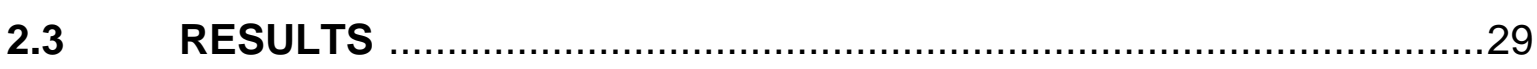



3 CHAPTER 2: COMPARISON OF ESTRADIOL BENZOATE DOSES FOR RESYNCHRONIZATION OF OVULATION AT 14 DAYS AFTER TAI IN SUCKLED BEEF COWS..........................................................35

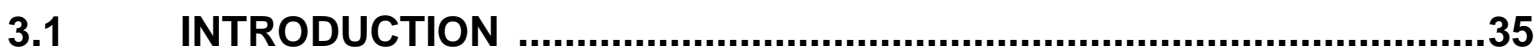

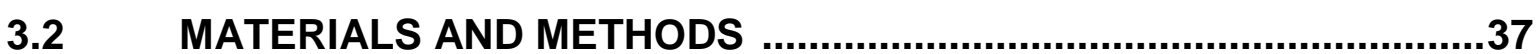

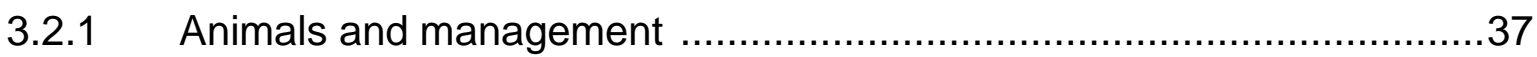

3.2.2 Reproductive management and treatments .........................................38

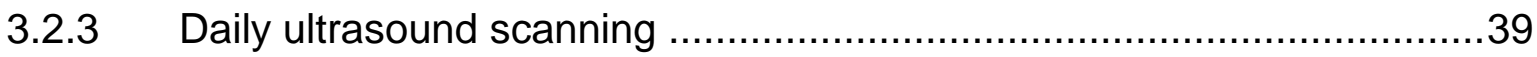

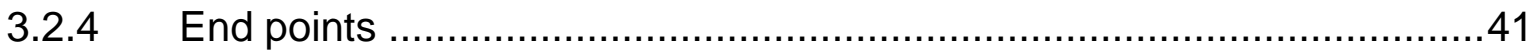

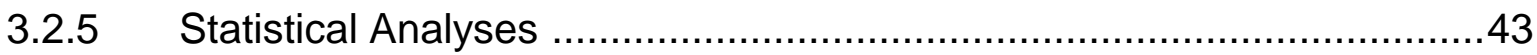

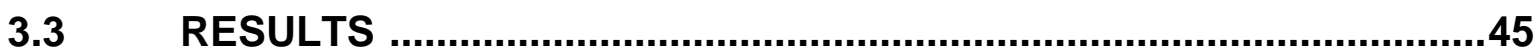

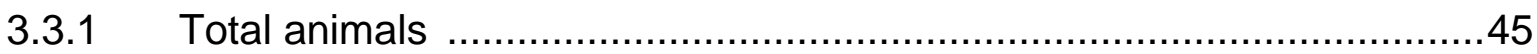

3.3.2 Subgroup submitted to daily ultrasound scanning ...............................48



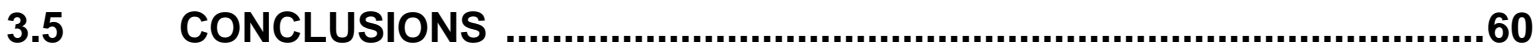

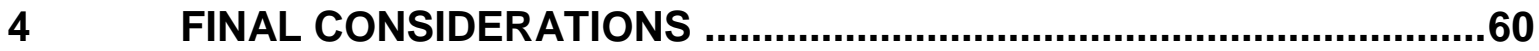

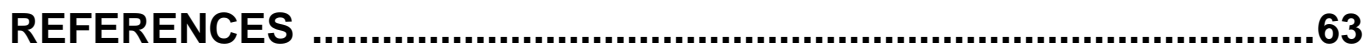

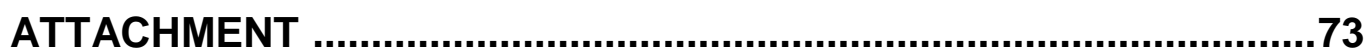




\section{INTRODUCTION}

Holder of the largest commercial bovine herd in the world and in the first place of beef exporters, Brazil has 187.5 million of head (ABIEC, 2021). Despite the significant and growing contribution of the livestock to the country's gross domestic product (CEPEA, 2021), for livestock to become a sustainable activity and to support the meat demands, there is a need for implementation of technologies in various sectors of the beef production chain. Among those, the breeding sector engages about $70 \%$ of the landing destined to livestock activity and has a great impact on the livestock's sustainability. However, low reproductive efficiency observed in Brazilian herds has a direct impact on the productivity and profitability of beef cattle (BARUSELLI; ZANATTA; ELLIFF, 2018).

A biotechnique that has contributed to improving reproductive efficiency is timed-artificial insemination (TAl). Among its advantages, the hormonal treatments used for the synchronization of ovulation needed for TAI induce the ovulation in most of suckled cows that are in post-partum anestrus. After a TAl cycle, cows are usually exposed to natural breeding; however, it is knowledge that a considerable number of females did not ovulate or return to anestrus condition after the first TAl cycle (ALVES et al., 2021). Another tool that has been contributing to the increase in reproductive efficiency is the use of resynchronization protocols (BARUSELLI et al., 2017). Different proposals for resynchronization protocols have been developed, starting before or after the pregnancy diagnosis. The conventional resynchronization protocol is performed only in females diagnosed as non-pregnant after the pregnancy diagnosis by B-mode ultrasonography, which is high accurate from $28-30$ days of pregnancy. Thus, the conventional resynchronization protocol allows an interval of $\approx 40$ days between inseminations. Alternatively, protocols can also be initiated before 
pregnancy diagnosis. For this, resynchronization can be started at 22 days after TAI when associated to the conventional B-mode ultrasonography, or even earlier, 12 to 14 days after TAl when using color Doppler ultrasonography for detection of nonpregnant animals that underwent luteolysis (PUGLIESI et al., 2019). Thus, it is possible to obtain intervals between inseminations of 32 or 22-24 days, respectively. Considering one service per estrus and an estrous cycle lasting 21 days (BARUSELLI et al., 2017), when using protocols starting 12 to 14 days after TAI, it is possible to increase the service rate to $95 \%$ [21/22 days].

When the resynchronization protocol is started close to the period of maternal recognition of pregnancy, the correct selection of drugs and its doses is needed so that the pre-existing pregnancy from first TAI is not harmed. In addition, it is necessary to ensure the synchronization of a new follicular wave emergence (FWE), aiming for the presence of a good-quality follicle at the end of the protocol (BINELLI; IBIAPINA; BISINOTTO, 2006). Estradiol benzoate (EB) associated with an intravaginal progesterone (P4) device are the most commonly used treatments at the beginning of the synchronization or resynchronization protocols on beef cattle in South America (BÓ et al., 1995; SÁ FILHO, et al., 2006, 2011). However, as estradiol (E2) may triggers the pulsatile release of prostaglandin $F_{2 \alpha}\left(P F_{2 \alpha}\right)$ and induces luteolysis, the EB treatment before pregnancy recognition period may risk the pregnancy establishment. Previous studies using E2 or EB before pregnancy recognition period have indicated controversial results. The administration of $1.5 \mathrm{mg}$ EB associated with an intravaginal P4 device 13 days after TAl negatively affected the pregnancy rate in dairy cows (VIEIRA et al., 2014). On the other hand, the use of $1 \mathrm{mg}$ EB associated with a P4 device 13 or 14 days after TAl in beef cows (PALHÃO et al., 2020) and heifers (MOTTA et al., 2020) did not risk the pre-existing pregnancy. 
Therefore, EB doses greater than $1 \mathrm{mg}$ may have negative impact on pre-existing pregnancy, but based on work carried out on Bos taurus cows (CACCIA; BÓ, 1998; BÓ et al., 2002; MARTÍNEZ et al., 2005a) the most efficient EB dose used at the beginning of the TAl protocol in suckled beef cows is $2 \mathrm{mg}$ (BÓ et al., 2002). In Bos indicus cows, the effects of different doses of EB were studied on resynchronization initiated on day 22 after TAI (PESSOA et al., 2015) or in non-lactating cows (BASTOS et al., 2011), and results also indicated that the FWE is more synchronized when 2 mg EB was used compared to lower doses.

Therefore, considering that there are few studies on the effect of EB doses in suckled Bos indicus cows, which are the majority animals used in the breeding herds in South America, two studies were developed to compare the effects of different EB doses on the synchronization and resynchronization of FWE and on the maintenance of pregnancy when used 14 days after TAl in suckled Bos indicus cows. 


\section{CHAPTER 1: COMPARISON OF THREE DOSES OF ESTRADIOL BENZOATE FOR SYNCHRONIZATION OF FOLLICULAR WAVE EMERGENCE IN SUCKLED BOS INDICUS BEEF COWS}

\subsection{INTRODUCTION}

Timed artificial insemination programs have been applied routinely on the last years in dairy and beef cattle herds, enabling the spread of artificial insemination (Al) (BISINOTTO; SANTOS, 2012). The E2/P4-based protocols have been the most used for Bos indicus or crossbred Bos indicus females in the tropical and sub-tropical regions, as this association has resulted in better pregnancy outcomes than the gonadotropin releasing hormone (GnRH)-based protocols (BARUSELLI et al., 2012). The association of E2 and P4 at the beginning of the protocol for TAl promotes atresia of the ovarian follicles and a new follicular wave emergence (FWE) (BÓ; BARUSELLI; MARTÍNEZ, 2003).

The EB is the most commonly used E2 ester at the beginning of the E2/P4-based protocols (BÓ et al., 1995; BURKE et al., 2001, 2003; MARTíNEZ et al., 2005b; SÁ FILHO, et al., 2006, 2011). The EB treatment induces, in a dose-dependent manner, the atresia of follicle stimulating hormone (FSH)-dependent follicles and a new FWE between 2 to 6 days post-treatment (BURKE et al., 2003; BASTOS et al., 2011). Although the conventional EB dose used at the beginning of the TAI protocol in suckled beef cows is $2 \mathrm{mg}$, a lower EB dose $(1 \mathrm{mg})$ has been indicated in beef heifers, as increased circulating E2 concentrations are observed in animals with lesser body weight and liver clearance (BÓ et al., 2002; MARTíNEZ et al., 2005a). A recent study (PESSOA et al., 2015) reported a more synchronized FWE in Bos indicus and Bos taurus suckled beef cows receiving $2 \mathrm{mg}$ than $1 \mathrm{mg}$ EB for 
resynchronization of ovulation 22 days after TAI. Therefore, an intermediate EB dose could be more adequate to increase the FWE synchrony for a second TAI and preferred to avoid the risk of pregnancy loss, but there is no study evaluating whether the use of an EB dose between 1 and $2 \mathrm{mg}$ can efficiently synchronize FWE. Also, for a better optimization of the TAI protocols, the differential effects of the EB/P4based protocol on synchronization of FWE between multiparous and primiparous suckled cows have to be determined. In this regard, primiparous beef cows have a lower reproductive performance and a greater nutritional demand compared to multiparous cows (SÁ FILHO et al., 2009; SÁ FILHO et al., 2010, 2013; SALES et al., 2016).

In the present study, we hypothesized that in suckled Bos indicus beef cows: 1 mg EB would not be efficient to synchronize a new FWE, but $1.5 \mathrm{mg}$ EB effectively synchronize the FWE as $2 \mathrm{mg}$. Therefore, we aimed to compare the ovarian follicular dynamics in primiparous and multiparous Bos indicus suckled beef cows receiving three different EB doses (1, 1.5 and $2 \mathrm{mg}$ ) for synchronization of FWE in a TAI protocol.

\subsection{MATERIALS AND METHODS}

\subsubsection{Animals and experimental design}

The experiment was approved by the ethics committee of the School of Veterinary Medicine and Animal Science of the University of São Paulo (protocol 3851080519) and was carried out at the São Paulo Agribusiness Technology Agency (Tietê, SP, Brazil). Thirty-six multiparous and 20 primiparous suckled Bos indicus cows (Nelore), $160 \pm 8.2$ days postpartum and with an average body condition score (BCS) $2.99 \pm 0.39$ (1 to 5 scale; 1 [emaciated] and 5 [obese]) were used. On a 
random day of the estrous cycle animals were submitted to an ovulation synchronization protocol (Figure 1). On day -10 (D-10), cows received an intravaginal P4-releasing device (Sincrogest ${ }^{\circledR}$, Ourofino Saúde Animal, Brazil) and were randomly assigned to either i.m. EB treatment: $1 \mathrm{mg}$ EB (Sincrodiol ${ }^{\circledR}$, Ourofino; EB-1 $[n=20,12$ multiparous and 8 primiparous]), $1.5 \mathrm{mg}$ EB (EB-1.5 $[n=15,9$ multiparous and 6 primiparous]) or $2 \mathrm{mg}$ EB (EB-2 [ $\mathrm{n}=21,15$ multiparous and 6 primiparous]). On D-2, the devices were withdrawn, and regardless of treatment group, all cows received: $1 \mathrm{mg}$ E2 cypionate ( $1 \mathrm{~mL}$; i.m., EC; SincroCP ${ }^{\circledR}$, Ourofino), $0.53 \mathrm{mg}$ sodium cloprostenol (2 mL; i.m., Cioprostinn ${ }^{\circledR}$, Boehringer-Ingelheim, Brazil), and $300 \mathrm{IU}$ equine chorionic gonadotrophin $\left(1.5 \mathrm{~mL}\right.$; i.m., eCG; SincroeCG ${ }^{\circledR}$, Ourofino). Cows were painted with chalk marker halfway between the hip and tail head to determine the occurrence of estrus between D-2 and D0. On D0, TAI was performed by a single technician with thawed semen from two sires.

A subgroup of multiparous [EB-1, $\mathrm{n}=8$; EB-1.5, $\mathrm{n}=9$; and EB-2, $\mathrm{n}=8$ ] and primiparous [EB-1, $\mathrm{n}=4$; EB-1.5, $\mathrm{n}=4$; and EB-2, $\mathrm{n}=2$ ] cows was subjected to daily ovarian evaluations by ultrasonography from D-10 to D0. Scanning was performed by a single operator using an ultrasound instrument (DP50-VET, Mindray, China) in B-mode with a linear multifrequency probe. Multiparous with a detected new FWE occurring from 3 to 5 days and primiparous with a detected new FWE occurring from 4 to 6 days after the treatment were considered to have a synchronized follicle wave emergence and the proportion of cows with a synchronized wave was calculated. The day of the new FWE was defined by retrospective evaluation, when the dominant follicle (DF) first appeared between 4 and $5 \mathrm{~mm}$ on the ultrasound image (GINTHER; KNOPF; KASTELIC, 1989). The follicular diameter was calculated by the mean of the maximum length and width using the caliper function. For estrous 
evaluations, they were scored from 0 to 3 , based on the color change between D-2 and D0, in which $0=$ unchanged, $1<50 \%$ of color removed, $2>50 \%$ of color removed and $3=100 \%$ of color removed. The occurrence of estrus was defined when the paint were classified as 2 or 3 . Ovulation was confirmed by disappearance of DF at the ultrasonographic exam $36 \mathrm{~h}$ after TAI. Pregnancy diagnosis was done on D37 by the transrectal ultrasonography to detect the presence of a viable embryo with heartbeat.

Figure 1. Schematic diagram of the experimental design.

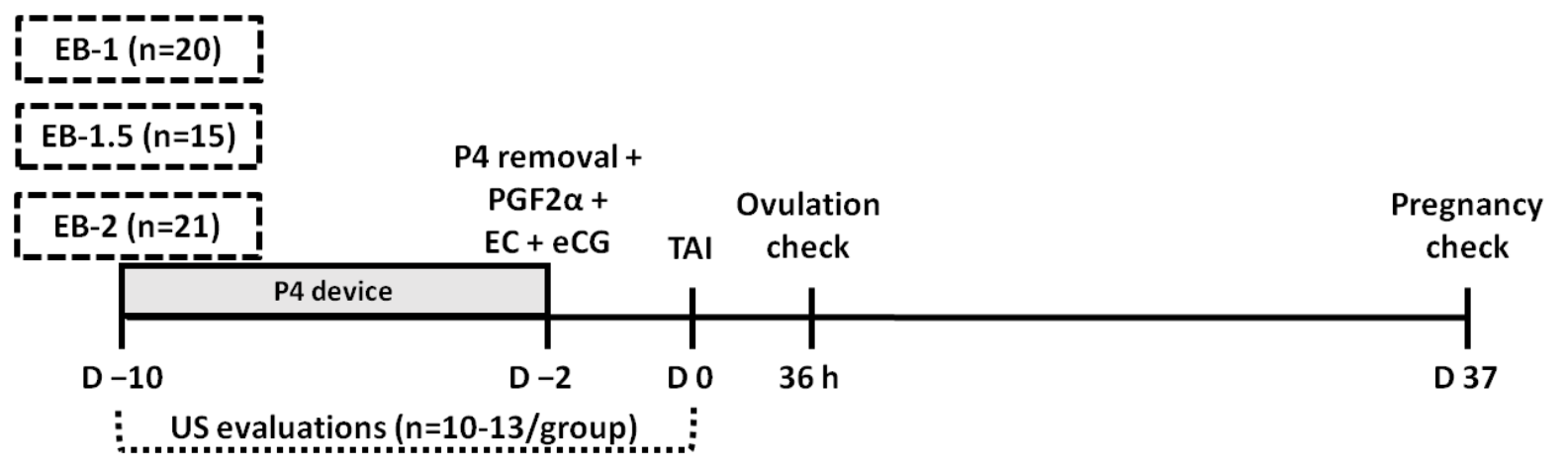

Source: (SILVA, A. G., 2021)

Notes: Schematic diagram of the experimental design. Suckled Nelore cows were submitted to a E2/P4 based TAl protocol and on D-10 were alocated in three groups: EB-1 (1 mg EB), EB-1.5 (1.5 mg EB) or EB-2 (2 mg EB) and all females reiceved a eight days-used P4 device. A subgroup $(n=10-$ 13 /group) were submitted to daily ( $D-10$ to $D 0$ ) ultrassonography evaluations (B-mode). On $D-2$, the devices were removed and all cows received $1 \mathrm{mg}$ E2 cypionate (EC), $0.53 \mathrm{mg}$ sodium cloprostenol (PGF2 $\alpha$ ), and $300 \mathrm{IU}$ equine chorionic gonadotrophin (eCG). The TAI was performed 48 hours after the treatment for induction of ovulation and the ovulation was checked 36 hours after TAI. The pregnancy diagnosis was performed through ultrasound B-mode on D37.

\subsubsection{Statistical Analyses}

Statistical analyses were performed using SAS software (version 9.2, SAS Institute Inc., USA). The continuous dependent variables (day of FWE, follicular growth rate and DF size) were evaluated for the normality of residues by the ShapiroWilk test and homogeneity of variances by Levene's test. Data were analyzed using ANOVA with the MIXED procedure considering only the main effects of treatment group (EB doses) and parity order, as the reduced number of primiparous cows in 
each treatment group limited the evaluation of a possible interaction between treatment and parity. The dispersion of the day of FWE was analyzed by Bartlett's test. The frequency of a new FWE that occurred from 3 to 5 days (multiparous) or 4 to 6 days (primiparous) post-treatment and the estrous, ovulation and pregnancy rates were compared by Fisher's exact test using FREQ procedure of SAS. Results are presented as mean \pm SEM and proportion. Probabilities of $p \leq 0.05$ indicate significant difference.

\subsection{RESULTS}

A new FWE was detected in all animal's subject to daily evaluations ( $n=35$ animals). There was no difference $(p>0.05)$ on the mean day of FWE among the treatment groups (Table 1$)$; however, a parity effect $(p=0.007)$ indicated a delayed FWE in primiparous than multiparous cows. When the dispersion of the detected day of FWE was analyzed by the Bartlett's test, no difference $(p>0.05)$ was detected among the treatment groups or parity categories (Fig. 2). Also, the proportion of cows with a synchronized FWE (multiparous, from 3 to 5 days post-treatment; and primiparous, from 4 to 6 days post-treatment) did not differ $(p>0.05)$ among the treatment groups (83\% [10/12], 85\% [11/13] and 70\% [7/10], for EB-1, EB-1.5 and EB-2 groups, respectively). 
Table 1. Follicular wave emergence (FWE), follicle growth rate, dominant follicle diameter at TAI of cows (multiparous and primiparous) treated with 1, 1.5, or $2 \mathrm{mg}$ EB at the beginning of the TAI protocol. All values are expressed as mean \pm SEM or proportions.

\begin{tabular}{|c|c|c|c|c|c|c|c|}
\hline & \multicolumn{3}{|c|}{ EB groups $^{\dagger}$} & \multicolumn{2}{|c|}{ Parity category* } & \multicolumn{2}{|c|}{$P$ value } \\
\hline & $\begin{array}{l}\mathrm{EB}-1 \\
(\mathrm{n}=20)\end{array}$ & $\begin{array}{l}\text { EB-1.5 } \\
(n=15)\end{array}$ & EB-2 $(n=21)$ & $\begin{array}{c}\text { PRIM } \\
(n=20)\end{array}$ & $\begin{array}{l}\text { MULT } \\
(n=36)\end{array}$ & $\mathrm{G}$ & C \\
\hline $\begin{array}{l}\text { Follicular wave } \\
\text { emergence, days }{ }^{\dagger *}\end{array}$ & $4.3 \pm 0.4$ & $3.9 \pm 0.3$ & $4.2 \pm 0.4$ & $5.1 \pm 0.4$ & $3.8 \pm 0.2$ & NS & 0.007 \\
\hline $\begin{array}{l}\text { Follicle growth rate from } \\
\text { FWE to TAI, mm/day }{ }^{\dagger *}\end{array}$ & $1.24 \pm 0.4$ & $1.19 \pm 0.08$ & $1.10 \pm 0.07$ & $1.06 \pm 0.05$ & $1.26 \pm 0.24$ & NS & NS \\
\hline $\begin{array}{l}\text { Diameter of largest } \\
\text { follicle at } D-2, \mathrm{~mm}\end{array}$ & $9.1 \pm 0.5$ & $9.5 \pm 0.5$ & $8.6 \pm 0.7$ & $7.8 \pm 0.7$ & $9.7 \pm 0.3$ & NS & 0.006 \\
\hline $\begin{array}{l}\text { Diameter of largest } \\
\text { follicle at TAl, mm }\end{array}$ & $11 \pm 0.6$ & $11.8 \pm 0.6$ & $11.1 \pm 0.6$ & $10 \pm 0.5$ & $11.9 \pm 0.4$ & NS & 0.008 \\
\hline $\begin{array}{l}\text { Cows detected in estrus } \\
\text { at TAI, \% }\end{array}$ & 85 [17/20] & 67 [10/15] & 86 [18/21] & 70 [14/20] & 86 [31/36] & NS & 0.02 \\
\hline Ovulation rate, \% & $75[15 / 20]$ & 67 [10/15] & 57 [12/21] & 55 [11/20] & 72 [26/36] & NS & NS \\
\hline Pregnancy rate, \% & $50[10 / 20]$ & $40[6 / 15]$ & $33[7 / 21]$ & $40[8 / 20]$ & $42[15 / 36]$ & NS & NS \\
\hline
\end{tabular}

Source: (SILVA, A. G., 2021)

${ }^{\dagger}$ Number of cows evaluated by daily ultrasonographic evaluations in each group, EB-1 $(n=12)$, EB-1.5 $(n=13)$ and EB-2 $(n=10)$;

* Number of cows evaluated by daily ultrasonographic evaluations in each parity order category, PRIM $(\mathrm{n}=10)$ and MULT $(\mathrm{n}=25)$;

$\mathrm{FWE}=$ follicular wave emergence; $\mathrm{TAl}=$ timed artificial insemination; $\mathrm{PRIM}=$ primiparous; $\mathrm{MULT}=$ multiparous; $G=$ Group effect; $C$ : category effect; $N S=$ Nonsignificant $(P>0.05)$.

The DF diameter (Table 1) was smaller in primiparous cows on D-2 $(p=$ $0.006)$ and at TAl $(p=0.008)$ but did not differ $(p>0.05)$ among the EB treatment groups. The proportion of cows detected in estrus at TAI did not differ $(p>0.05)$ among the treatment groups (Table 1$)$, but a category effect $(p=0.02)$ reflected a greater proportion of multiparous cows detected in estrus than primiparous cows. No difference $(p>0.05)$ was observed for the follicle growth rate $(\mathrm{mm} /$ day) from FWE to TAl among the EB treatment groups nor between primiparous and multiparous cows (Table 1). Also, no effect $(p>0.05)$ of treatment group or parity was observed on ovulation and pregnancy rates (Table 1). 
Figure 2: Individual values to day of follicular wave emergence in multiparous ( $\mathbf{\Delta})$ and primiparous (o) cows.

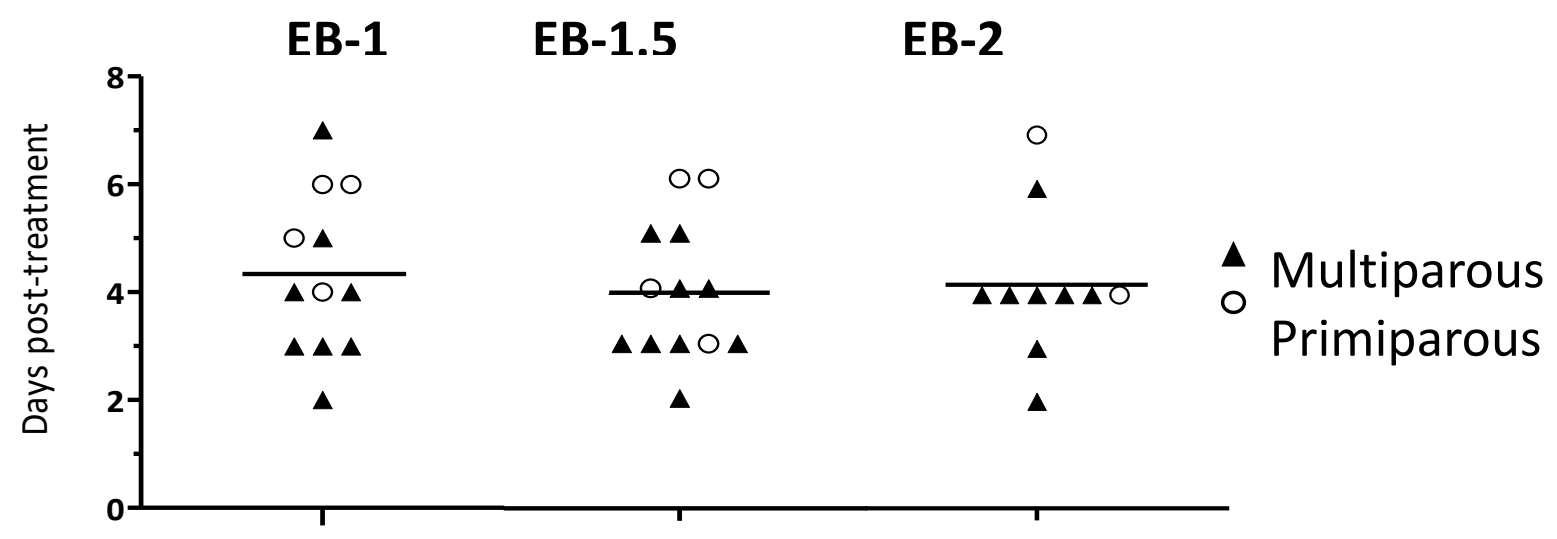

Source: (SILVA, A. G., 2021)

Notes: The horizontal bars represent the aritmetric mean for each treatment. The dispersion of the detected day of FWE did not differ among the treatment groups when analyzed by Bartlett's test $(p>0.05)$.

\subsection{DISCUSSION}

In the present study, three EB doses (1, 1.5 and $2 \mathrm{mg}$ ) were used simultaneously for the first time to compare its effects on FWE and DF characteristics in suckled Nelore cows, aiming to define which EB dose is better to effectively synchronize FWE in suckled Nelore cows. A control group (without EB treatment) was not included as the objective was to compare the doses already used in TAI protocols and where the insertion of the P4 device without E2 administration is known to lead to follicular persistence (KINDER et al., 1996). Also, a limitation of the herein study is that an interaction between EB dose and parity order was not evaluated due to the limited number of primiparous cows receiving each EB dose. Our expectation that $1 \mathrm{mg}$ EB would not be efficient to synchronize a new FWE in suckled beef cows was not supported. The FWE was not affected by the EB dose used at the beginning of the protocol and 83\% [10/12] of cows that received $1 \mathrm{mg} \mathrm{EB}$ had a synchronized FWE (FWE occurring in a range of three days). A similar efficacy 
of $1 \mathrm{mg}$ EB compared to $2 \mathrm{mg}$ has been previously reported in suckled Bos taurus and Bos indicus beef cows and Bos taurus dairy cows, both non-lactating (Burke et al., 2003; Bastos et al., 2011). But, when these both doses were in Bos indicus suckled cows for resynchronization on day 22 after TAI (PESSOA et al., 2015), the FWE occurred more dispersed in cows treated with $1 \mathrm{mg}$ EB. This divergence between the previous and present results may be related to several factors affecting circulating E2 concentrations at the time of EB treatment, as the size of DF and the liver clearance of steroid hormones. According to Sartori et al. (2016), Bos indicus cows have a slower metabolism of steroid hormones, compared to Bos taurus cows. In addition, increased clearance of steroid hormones is directly correlated with high dry matter intake and lactation (SANGSRITAVONG et al., 2002). Thus, the $1 \mathrm{mg}$ EB dose at the beginning of the protocol may be appropriate to synchronize the FWE in cows kept on pastures without feed supplementation or in late postpartum period (reduced milk yield), as well as in the present study.

Although the comparison of intermediate EB doses as $1.5 \mathrm{mg}$ with other doses has not been reported for Bos indicus females, a study with suckled Hereford and Hereford x Charolais crossbreed (PFEIFER et al., 2018) using $1.5 \mathrm{mg}$ EB associated to a $0.78 \mathrm{~g} \mathrm{P4}$ device reported that only $52.4 \%$ [11/21] of suckled beef cows had follicular atresia and a new FWE. The results obtained with the present study supported our hypothesis that $1.5 \mathrm{mg}$ EB effectively synchronize the FWE in Bos indicus beef cows, regardless the parity order. That is, the dose of $1.5 \mathrm{mg}$ induced a new FWE between 3 to 6 days after the EB treatment in $75 \%$ of primiparous and $88 \%$ of multiparous cows. Also, similar DF size, proportion of cows detected in estrus and ovulation and pregnancy rates were observed in cows treated with 1.5 or $2 \mathrm{mg}$ EB. 
Regarding the parity effect on follicular dynamics, the present study indicated one day delay in FWE and a reduced DF size at P4 device removal and at TAI in primiparous than multiparous Nelore cows. The delay in FWE may be resulting from a longer FSH suppression caused by increased circulating E2 in primiparous than multiparous, as first parous cows at calving are about $85 \%$ of adult weight (DISKIN; KENNY, 2014). Consequently, primiparous cows are lighter after partum (UNGERFELD et al., 2011), have greater weight loss during early postpartum, and present $7 \%$ less body weight than the multiparous (second calving order) at the weaning period (VIEIRA et al., 2005).

The reduced DF size in primiparous cows could be a direct consequence of the delayed FWE, resulting in a short period for DF growth between follicle deviation to TAI. Still, a reduced gonadotropin support for final DF growth is associated as the primary cause for a smaller DF in primiparous cows, as a lower circulating $\mathrm{LH}$ pulsatility and IGF-I concentration is reported in primiparous than multiparous cows (MEIKLE et al., 2004). Also, primiparous cows have a greater energy demand than multiparous, as they need energy for lactation and body growing (NRC, 2016). Consequently, a more severe anestrous condition and lower reproductive performance during early postpartum is reported in primiparous than multiparous Bos indicus cows subjected to TAl protocols (SÁ FILHO et al., 2009, 2013; SALES et al., 2016). The delayed FWE and reduced gonadotropin support for follicle grow might be associated for leading to a smaller DF at TAl in primiparous cows, which has a positive and linear relationship with pregnancy rates in TAI programs of beef cattle (SÁ FILHO et al., 2011; PUGLIESI et al., 2016; NISHIMURA et al., 2018). Therefore, the hormonal protocols for TAI in primiparous suckled cows would be modified to allow an extended period or greater gonadotropin support for follicle grow during the 
LH-dependent phase aiming to improve reproductive performance. Thus, the reduction in 25 to $50 \%$ of the conventional EB dose $(2 \mathrm{mg})$ for synchronization of FWE at beginning of the E2/P4-based protocol could be an interesting alternative with high efficiency in induction of a new FWE for situations with lighter cows or for super-early resynchronization protocols, where doses greater than 1 mg EB may negatively affect the previous pregnancy (SILVA et al., 2020). Though, because of the limited number of animals used in the present study, further studies are needed to evaluate the effect of reduced EB doses on the pregnancy rate in suckled beef cows.

In conclusion, the EB doses varying from 1 to $2 \mathrm{mg}$ proved to be efficient to synchronize the emergence of a new follicular wave in suckled Nelore cows. The delayed FWE in primiparous cows is a factor contributing to the reduced DF diameter at TAI compared to multiparous cows, indicating that the TAI protocols in first parous cows should be modified to allow an extended time for gonadotropin support from FWE to TAI. 


\section{CHAPTER 2: COMPARISON OF ESTRADIOL BENZOATE DOSES FOR RESYNCHRONIZATION OF OVULATION AT 14 DAYS AFTER TAI IN SUCKLED BEEF COWS}

\subsection{INTRODUCTION}

Resynchronization of ovulation programs allow the expanding of TAl use in cattle, and consequently accelerate the genetic gain due to the increase in the number of calves born from $\mathrm{Al}$ and reduce the number of bulls needed in the breeding farms (BARUSELLI et al., 2017). Another important impact of resynchronization programs is that it may result in greater pregnancy rates when compared to TAI protocols followed by natural mating (CREPALDI et al., 2017). This result is caused mainly by a great proportion of non-pregnant cows that return to anestrus condition after first TAI (ALVES et al., 2021), especially those with low body condition (AYRES et al., 2009). Thus, these animals have a second chance of induction of ovarian activity after partum with the resynchronization program. Among the possibilities of resynchronization, the protocols starting 14 days after the first TAI allow an interval between TAls of 24 days and provide a service rate up to $87.5 \%$ (BARUSELLI et al., 2017). For performing this method, the evaluation of CL function by color-Doppler ultrasonography is fundamental to detect with high accuracy the luteolysis 20 to 22 days after TAI in females which failed to conceive (SIQUEIRA et al., 2013; PUGLIESI et al., 2014; DALMASO DE MELO et al., 2020).

Because hormonal treatments in these protocols precede the time of maternal pregnancy recognition in cattle (BINELLI et al., 2001), there should not be a risk to pre-existing pregnancies and the treatment regimen must be effective in synchronizing the timing of FWE for conducting a second TAI. Therefore, the association between $\mathrm{P} 4$ and EB treatments when the resynchronizations start in the 
second week after TAl may influence the establishment of pregnancies because of the function of E2 in inducing luteolytic $\mathrm{PGF}_{2 \alpha}$ pulses from endometrium (ARAUJO et al., 2009; PUGLIESI et al., 2012). When the administration was close to the period of maternal recognition of pregnancy (12 to 14 days post-TAI), inconsistent results were observed regarding the impact on pregnancy maintenance. The administration of 1.5 mg EB associated with an intravaginal P4 device 13 days after TAI negatively affected the pregnancy rate in dairy cows (VIEIRA et al., 2014). In contrast, administration of $1 \mathrm{mg}$ EB associated to an intravaginal P4 device 14 days post-TAI did not affect the pregnancy rate from first TAI in beef heifers (MOTTA et al., 2020). Also, the pregnancy rate in the first TAl did not differ between beef suckled cows resynchronized at 13 days after TAI with $1 \mathrm{mg}$ EB associated with an intravaginal P4 device and non-resynchronized control animals (PALHÃO et al., 2020).

In resynchronization programs starting 22 days after first TAI, the use of 1 or 2 mg of EB did not affect the pregnancy rate of the first TAI (SÁ FILHO et al., 2014; PESSOA et al., 2015); whereas the FWE was more synchronized and pregnancy rates were greater in suckled cows receiving 2 mg EB. Palhão et al. (2020) reported satisfactory pregnancy rates at the second TAl when using $1 \mathrm{mg} E B$ in the resynchronization program starting at day 13; however, the effects of $2 \mathrm{mg} E B$ on FWE and pregnancy rates in suckled beef cows submitted to resynchronization program at day 12-14 after TAl are not known. Therefore, administration of smaller doses of EB might be a safe alternative for not risking the establishment of pregnancy (MOTTA et al., 2020), but these regimens may also be ineffective for synchronizing the time of FWE among suckled beef cows.

In this context, it is necessary to assess whether a dose of $1 \mathrm{mg}$ EB is sufficient to synchronize the FWE when P4 concentrations are elevated as expected 
at the beginning of resynchronization protocols at 12-14 days after TAl. As well as to evaluate whether increasing the dose of EB to $2 \mathrm{mg}$ impairs the pregnancy rate when administered close to the period of maternal recognition of pregnancy. Therefore, we aimed with this study to compare the effects of use of 1 or $2 \mathrm{mg} \mathrm{EB}$ administered at the beginning of resynchronization at 14 days after TAl on: 1) corpus luteum $(\mathrm{CL})$ maintenance and synchronization of FWE, 2) pregnancy rate and potential embryonic loss from the first TAl; and 3) pregnancy rate for cows resynchronized and submitted to the second TAl. We hypothesized that: 1) the $2 \mathrm{mg}$ dose induces a more synchronized FWE; 2) the pregnancy establishment from the first TAI is not impacted by the EB dose; and 3) animals receiving 2 mg EB would have a greater pregnancy rate at resynchronization.

\subsection{MATERIAL AND METHODS}

Experiments were submitted and approved by the ethics committee of the School of Veterinary Medicine and Animal Science of the University of São Paulo institution, under the protocol number 3851080519.

\subsubsection{Animals and management}

Experiment was carried out between the months of November and March (breeding season 2019-2020) in two farms located in the states of Sao Paulo and Mato Grosso, Brazil. A total of 1,026 Bos taurus indicus suckled beef cows (968 multiparous and 58 primiparous) with an average of 45 days post-partum and body condition score between 2.5 and 4 at TAI (BCS; on a scale of 1 to 5 , in wich 1 [emaciated] and 5 [obese]; AYRES et al., 2009) were used. Cows were kept on Brachiaria decumbens, Brachiaria humidicola, Brachiaria brizantha (cv Marandu), 
Andropogon gayanus and Panicum maximum (cv Mombaça) pastures with ad libitum access to water and a mineralized salt. Thirty-seven multiparous cows received supplementation with corn silage and concentrate as established by the NRC (2016) during the experimental period.

\subsubsection{Reproductive management and treatments}

On a random day, all cows were submitted to an ovulation synchronization E2/P4-based protocol (10 days of length), accordingly to the conventional protocol used in each farm. Briefly, cows received an intravaginal P4-releasing device (Sincrogest $^{\circledR}$; or Progestar $^{\circledR}$, Boehringer Ingelheim, Brazil) along with an i.m. administration of 2 mg EB (RIC-BE ${ }^{\circledR}$, Tecnopec Ltda, São Paulo, Brazil) or 5.5 mg 17ß-E2 (Betaproginn ${ }^{\circledR}$, Boehringer-Ingelheim). On D-2 the devices were withdrawn and was performed the administration i.m of 0.394 or $0.530 \mathrm{mg}$ sodium cloprostenol (Estron $^{\circledR}$, Agener União, São Paulo, Brazil or Cioprostinn ${ }^{\circledR}$, Boehringer Ingelheim), 0.6 or 1 mg E2 cypionate $\left(\mathrm{ECP}^{\circledR}\right.$, Zoetis Brazil - Saúde Animal, São Paulo or SincroCP ${ }^{\circledR}$ ) and 300 IU eCG $\left(\right.$ Novormon $^{\circledR}$; or Folligon ${ }^{\circledR}$, MSD Saúde Animal, São Paulo, Brazil). Cows were inseminated 48 hours after withdrawn by five experience operators with thawed semen from ten sires. The day of first TAI was considered as D0.

Fourteen days (D14) after first TAl cows received an 8 or 16 days-used intravaginal P4-releasing device (Sincrogest ${ }^{\circledR}$, Ourofino Saúde Animal, Cravinhos, SP, Brazil) and were randomly subdivided into two experimental groups: EB-1 [n = 516] or EB-2 [ $\mathrm{n}=510$ ], that received 1 or 2 mg EB (1 or $2 \mathrm{~mL}$, i.m., Sincrodiol ${ }^{\circledR}$, Ourofino Saúde Animal), respectively. Along with the beginning of resynchronization, a subset of cows ( $n=933$ ) was submitted to ovarian ultrasound scanning to detect 
presence of an active CL. On D22, an early diagnosis of pregnancy was performed by a color-Doppler ultrasonography (Mindray Z5 Vet, Shenzhen, China) with a linear multi-frequency B-mode transducer (frequency 7.5 MHz; D 6.5; gain 71; FR 22; DR 120) and in Doppler mode (5.7 MHz, gain 72, WF 260, PRF 0.7kHz). Cows with a functional $\mathrm{CL}$ (> $25 \%$ of blood perfusion) on D22 were considered pregnant and had only the intravaginal P4 device removed. In non-pregnant cows, the resynchronization protocol was continued by administration of $1 \mathrm{mg}$ E2 cypionate (1 mL, i.m., SincroCP ${ }^{\circledR}$, Ourofino Saúde Animal), 0.53 mg sodium cloprostenol (2 mL, i.m., Sincrocio ${ }^{\circledR}$, Ourofino Saúde Animal) and 300 IU equine chorionic gonadotropin (eCG; $1.5 \mathrm{~mL}$; Novormon ${ }^{\circledR}$, Zoetis Brasil - Saúde Animal). Still on D22, in a subset of non-pregnant cows (283/488) estrous detection patches (Boviflag ${ }^{\circledR}$, ABS Pecplan, Uberaba, MG, Brazil) were applied halfway between the hip and tail head to determine the occurrence of mounting behavior associated with estrus between D22 and D24. On D24, cows which luteolysis was detected by color Doppler, were reinseminated in fixed time with thawed semen from seven sires and by seven operators. The semen and the operators were equally assigned for two treatment groups. The confirmatory diagnosis of pregnancy was assessed by ultrasound evaluations, between 30 and 35 days after first TAI, by detection of an embryo with heartbeats. The pregnancy diagnosis of the second TAl also was performed with an interval of 30-35 days (D54-D59).

\subsubsection{Daily ultrasound scanning}

Thirty-seven cows ( $n=18-19 /$ group) had the ovulation checked 48 hours after first TAl and were subject to daily ultrasound evaluations from D14 to D22 after first TAl to map the localization and size of follicles and to determinate the area and blood 
perfusion of CL. Daily evaluations were performed by a single operator with a duplex

B-mode and pulse-wave Color-Doppler ultrasound instrument (MyLab Delta, Esaote

Healthcare, Italy), with a linear multifrequency transducer $(3,5-7,5 \mathrm{MHz})$ in $\mathrm{B}$ mode (RES-A, gain 50\%, P 74mm, X/M, PRS 1) and Color-Doppler mode (gain $61 \%$, PRF $730 \mathrm{~Hz}$, frequency $6,3 \mathrm{MHz}, \mathrm{WF} 4, \mathrm{PRS} 3, \mathrm{PRC} \mathrm{M} / 2)$. Still in these animals, the ovulation check was performed 48 hours after second TAl by transrectal ultrasonography.

Figure 3 - Schematic diagram of the experiment.

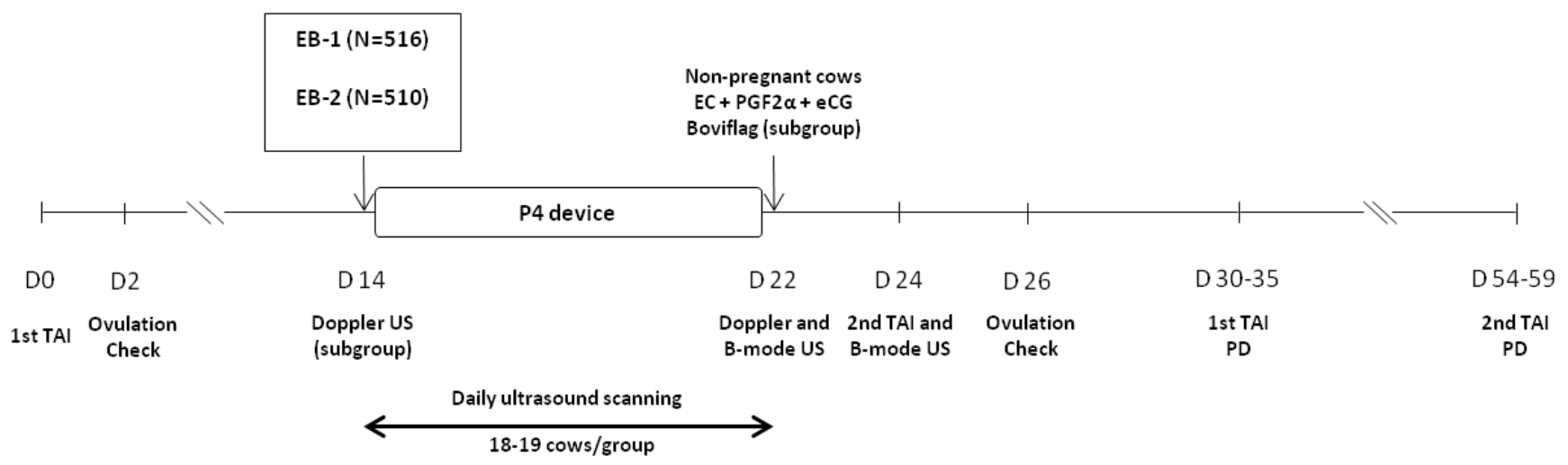

Source: (SILVA, A. G., 2021)

Notes: 1,026 suckled Nelore cows were submitted to TAI (D0). On D14, cows received a P4-releasing device 8/16 days used and were assigned in two experimental groups: EB-1 ( $n=516$ cows) or EB-2 ( $n$ $=510$ cows) that received respectively, 1 or $2 \mathrm{mg} \mathrm{EB}$ according to BCS at TAI. Beyond of the start of resynchronization protocol, a subgroup of cows $(n=933)$ were evaluated by transrectal ultrasonography to detect absence of CL. On D22, P4 devices were removed and early diagnosis was performed by luteolysis detection using color Doppler ultrasonography. Cows which presented an active CL had only P4 devices removed while cows which luteolysis was detected, followed on protocol and received i.m. $1 \mathrm{mg}$ of E2 cypionate, $0.530 \mathrm{mg}$ of sodium cloprostenol and $300 \mathrm{IU}$ of eCG. Also, on D22, cows that which underwent to luteolysis were submitted to B-mode ultrasonography evaluations to measure the largest follicle size and a subgroup of non-pregnant cows were used estrous detection patches $\left(\right.$ Boviflag $\left.^{\circledR}\right)$. On D24, cows with the luteolysis detected by Doppler were submitted to second TAI, had the largest follicle measure and, were assigned the estrus scores based on color change of estrous patches. Confirmatory pregnancy diagnosis was performed between D3035 after first or second TAl. A subgroup of cows (18-19 cows/group) was submitted to ovulation check after first TAl and daily ultrasound scanning (B-mode and color Doppler) from D14-D22. On D22 P4devices were removed and cows were evaluated using Color Doppler Ultrasonography. Cows which underwent to luteolysis had the ovulation checked by transrectal ultrasonography 48 hours later second TAI. 


\subsubsection{End points}

The day of the new FWE was defined by means of a retrospective evaluation, when the largest follicle first appeared between 4 and $5 \mathrm{~mm}$ (GINTHER; KNOPF; KASTELIC, 1989). Cows with a detected new FWE occurring between 3 to 5 days after the treatment (D17-19) were considered to have a synchronized FWE and the proportion of cows with a synchronized wave was calculated. Cows without a detected new FWE or with presence of a persistent dominant follicle from D14 to D22 were omitted from this analysis (EB-1, $n=5$; and EB-2, $n=1$ ). The day of structural luteolysis was defined by a retrospective evaluation as the day when the $\mathrm{CL}$ presented for the first time a blood perfusion $\leq 25 \%$ (PUGLIESI et al., 2014). Corpus luteum data of four cows submitted to daily evaluations ( $n=2 /$ group) were excluded of repeated measurement due to the presence of $2 \mathrm{CL}$ in the ovaries from double ovulation.

The diameter of the follicles was calculated by the mean of the maximum length and width using the caliper function while the $\mathrm{CL}$ area were performed through the function tracing in B mode, in which they were measured and recorded in a schematic design. When the CL presented a cavity, it was subtracted from the total luteinized area, as previously described by Rocha et al. (2019). The animals were submitted to evaluations of the blood perfusion of $\mathrm{CL}$ with color-Doppler ultrasonography in which the area with colored signals was considered and a percentage was estimated in relation to the total CL area (PUGLIESI et al., 2014). Ovulation was confirmed by disappearance of the dominant follicle at the ultrasonographic exam $48 \mathrm{~h}$ after the $1^{\text {st }}$ and $2^{\text {nd }}$ TAl. 
On D14 along with the beginning of resynchronization, a subgroup of cows (n =933) was submitted to ovarian ultrasound scanning to detect presence of an active $\mathrm{CL}$ at the beginning of protocol. On D22, cows that underwent luteolysis $(n=235$ of EB-1 and $n=267$ of EB-2) had the diameter of the largest follicle measured by taking the mean of the maximum length and width using the caliper function. In a subset of cows that underwent luteolysis $(283 / 502)$ estrous detection patches (Boviflag ${ }^{\circledR}, A B S$ Pecplan, Uberaba, MG, Brazil) were applied halfway between the hip and tail head to determine the occurrence of mounting behavior associated with estrus. For evaluation, they were scored from 0 to 3 , based on the color change between the application and the second TAI (D24), in which $0=$ unchanged, $1<50 \%$ color change, $2>50 \%$ of change in color, and $3=100 \%$ change in color. The occurrence of estrus was defined when the patches were classified as 2 or 3 . Cows that had the luteolysis detected on D22 by Color-Doppler were submitted to a second TAI 48 hours later (D24) and had the ovaries scanning for measurement of the largest follicle and evaluation of the growth rate of this follicle in a 48-h interval (D22 to D24).

Proportion of cows with an active CL on D14 was calculated based on the number of cows with a functional CL over on the number of cows evaluated. Proportion of cows with an active CL on D22 was calculated based on the number of animals with a functional CL over on the number of cows inseminated. Pregnancy per $\mathrm{Al}(\mathrm{P} / \mathrm{Al})$ from first TAl was calculated based on the number of animals with an embryo with heartbeats over on the number of cows inseminated. Potential embryonic loss was considered in two experimental periods. Potential early embryonic loss (PEEL; from D14 to D22) was considered as the number of cows without active $\mathrm{CL}$ on $\mathrm{D} 22$ over on the number of cows with active $\mathrm{CL}$ at the beginning of the resynchronization protocol (into the subgroup evaluated on D14, $n=933$ ). The 
potential late embryonic loss (PLEL; from D22 to D30-35) was considered as the number of cows without a viable embryo in the confirmatory pregnancy diagnosis (D30-35) over on the number of cows with active $C L$ on D22. P/Al from second TAI was calculated based on the number of cows with an embryo with heartbeats on D54-59 over on the number of cows submitted to the second TAI. Cumulative P/AI was calculated based on the number of cows diagnosed as pregnant in the confirmatory diagnoses after first and second TAls over on the total number of cows exposed to the TAI program. Sixteen cows were excluded for the calculation of the P/Al after second TAl due to management issues. Thus, for the calculation of cumulative pregnancy rate 1,010 cows were considered.

\subsubsection{Statistical Analysis}

All statistical analyzes were performed using SAS (version 9.2, SAS Institute Inc., Cary, NC, USA). The experiment was conducted as a completely randomized design and every cow as an experimental unit. BCS of cows at first TAl was used for balanced distribution of treatment groups. The continuous dependent variables (day of new FWE, follicular size, day of structural luteolysis, CL size and blood perfusion) were evaluated for the normality of the residues by the Shapiro-Wilk test and homogeneity of variance by Levene's test. When the raw data did not follow normal distribution, data were transformed into natural logarithms or ranked. Data were analyzed by ANOVA using PROC MIXED considering the effects of treatment group (EB-1 and EB-2), pregnancy status (pregnant or non-pregnant), day (for repeated measurements of CL characteristics) and their possible interactions. As we observed that on D14, blood perfusion was different between EB treatment groups, the CL 
blood perfusion on $\mathrm{D} 14$ was used as a covariate $(P=0.0001)$ for repeated measurements. The average values were compared between days, when necessary using Fisher's protected least significant difference (LSD, i.e., the DIFF option of the LSMEANS statement). The dispersion of the day of FWE was analyzed by Bartlett's test. The frequency of FWE that occurred between days 3 and 5 after treatment was evaluated by Fisher's exact test using the PROC FREQ of SAS.

The dependent variables, presence of $C L$ on D14, pregnancy rate, potential embryonic loss and occurrence of estrus, were analyzed by the GLIMMIX procedure using a binomial distribution. Multivariable models were built, and a backward stepwise elimination method was applied, considering the Wald's criterion (factors with $\mathrm{P}>0.2$ are excluded from the model). For presence of $\mathrm{CL}$ on $\mathrm{D} 14$, pregnancy rate, potential embryonic loss and occurrence of estrus, the initial statistical model was composed of the fixed effects of treatment group $(n=2)$, P4 device $(n=2)$, categories of body condition score based on the median BCS $(n=2, B C S<3$ or BCS $\geq 3$ ), and their possible interactions. For the random effects, parity category (primiparous or multiparous), sire $(n=8)$ and technician $(n=8)$ nested in the farm were included in the model. Therefore, the final models for presence of CL on D14, pregnancy rate, potential embryonic loss and the occurrence of estrus included only the effects of treatment group and body condition score. Results were expressed as mean \pm SEM. Significant differences were declared at $P \leq 0.05$ and a tendency was declared when $P \leq 0.1$ and $P>0.05$. 


\subsection{RESULTS}

\subsubsection{Total animals}

The proportion of cows bearing an active CL on D14 did not differ $(P>0.1)$ between the EB-1 and EB-2 groups (Fig.4), but was affected $(P<0.05)$ by the BCS. A greater proportion of $C L$ was observed in cows with a $B C S \geq 3$ than cows with $B C S$ $<3$ (Table 2). The PEEL, which was based on ratio of cows without active CL on D22 over the number of cows with active CL at D14 was 40\% [332/830]. The PEEL was greater $(P<0.05)$ in the EB-2 group than in the EB-1 group (Fig.5), but was not affected $(P>0.1)$ by the BCS (Table 2$)$.

Figure 4 - Proportion of cows (\%) with an active $\mathrm{CL}$ at beginning of resynchronization protocol (D14) and at Doppler ultrasonography (D22) and with an embryo on B-mode diagnosis (D30-35) after first TAl.

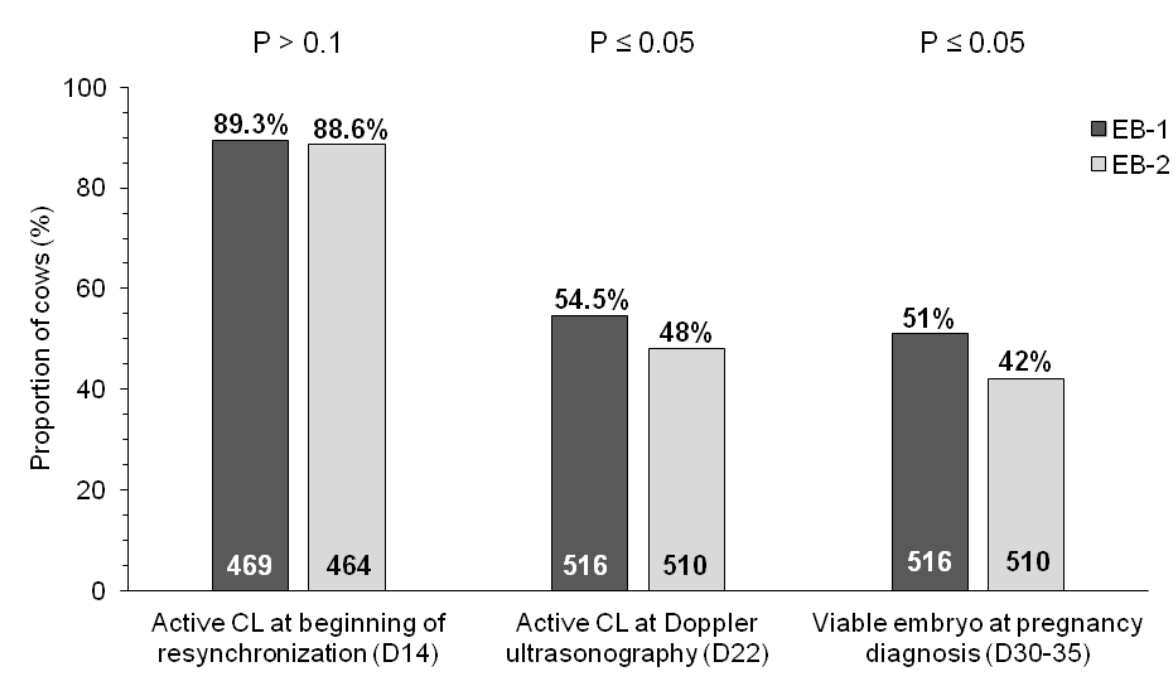

Source: (SILVA, A. G., 2021)

Notes: Proportion of cows with an active $\mathrm{CL}$ at beginning of resynchronization protocol (D14), at Doppler diagnosis (D22) and pregnancy rate at the B mode diagnosis (D30-35) in beef cows resynchronized 14 days after TAl with an intravaginal P4 device associated to 1 (EB-1; $n=516$ ) or 2 $\mathrm{mg}(\mathrm{EB}-2 ; \mathrm{n}=510)$ of estradiol benzoate $(\mathrm{EB})$. Significant differences were declared at $\mathrm{P} \leq 0.05$ and a tendency was declared when $P \leq 0.1$ and $P>0.05$.

The overall pregnancy rates at D22 and D30-35 were 51.1\% [524/1026] and $46.4 \%$ [476/1026], respectively, and were affected $(P<0.05)$ by the treatment group and the BCS. The proportion of cows with an active $\mathrm{CL}$ at $\mathrm{D} 22$ and P/AI at D30-35 
after first TAI was greater in the EB-1 than in the EB-2 group (Fig.4). The BCS effect indicated that in cows with $\mathrm{BCS} \geq 3$ the pregnancy rate was greater compared to those with a BCS < 3 (Table 2). The overall PLEL between Doppler diagnosis (D22) and confirmatory diagnosis of pregnancy (D30-35) was 9.2\% [48/524] and was affected $(P<0.05)$ by treatment group as well as a tendency $(P=0.08)$ for a BCS effect. The group effect reflected that the PLEL was greater in EB-2 than EB-1 group (Fig. 5). In addition, the PLEL tended to be greater in cows with a BCS $<3$ than in cows with $\mathrm{BCS} \geq 3$ (Table 2). For the follicular characteristics of non-pregnant cows detected by Doppler ultrasonography on D22 and submitted to the second TAI, no difference $(P>0.1)$ was observed between groups in the size of the largest follicle at D22 (10.13 \pm 0.15 vs. $9.6 \pm 0.13 \mathrm{~mm}$, for EB-1 and EB-2 respectively) and at TAl (11.98 \pm 0.17 vs. $11.54 \pm 0.16 \mathrm{~mm}$, for EB-1 and EB-2 respectively). Also, the growth rate of largest follicle between P4 device withdrawal (D22) and the TAI (D24) did not $\operatorname{differ}(P>0.1)$ between the EB-1 $(0.80 \pm 0.07 \mathrm{~mm} /$ day $)$ and EB-2 (0.87 \pm 0.07 $\mathrm{mm} /$ day) groups. Accordingly, the occurrence of estrus did not differ $(P>0.1)$ between the EB-1 (38.5\% [47/123]) and EB-2 (35.6\% [57/160]) groups.

Figure 5 - Proportion (\%) of potential early embryonic loss (PEEL) from D14 to D22 and late embryonic loss (PLEL) from D22 to D30-35 between treatment groups.

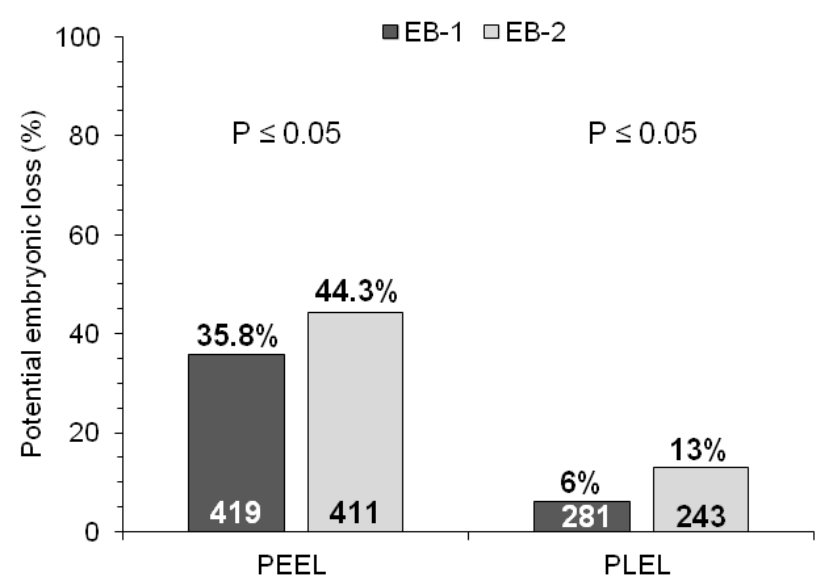

Source: (SILVA, A. G., 2021) 
Notes: PEEL (Potential early embryonic loss) $=$ Number of cows without an active CL at Doppler diagnosis (D22) over on the number of cows with an active CL at the beginning of resynchronization protocol (D14); PLEL (Potential late embryonic loss) = Number of cows without an embryo at B mode diagnosis (D30-35) over on the number of cows with an active CL at Doppler diagnosis (D22). Significant differences were declared at $P \leq 0.05$ and a tendency was declared when $P \leq 0.1$ and $P>$ 0.05 .

Table 2. Effect of body condition score (BCS) on the proportion (\%) of cows with an active CL at days 14 and 22 after TAI, pregnancy rate from first TAI, potential early embryonic loss, potential late embryonic loss, and cumulative pregnancy rate [TAl 1 + TAl 2].

\begin{tabular}{lccc}
\hline End point, \% [n/N] & BCS $<3$ & BCS $\geq 3$ & $P$-value \\
\hline Proportion of cows with an active CL on D14 $^{\mathrm{a}}$ & $82.7[234 / 283]$ & $91.7[596 / 650]$ & $<0.0001$ \\
Proportion of cows with an active CL on D22 $^{\mathrm{b}}$ & $43.5[137 / 315]$ & $54.4[387 / 711]$ & 0.001 \\
Pregnancy rate at D30-35 $^{\mathrm{c}}$ & $37.8[119 / 315]$ & $50.2[357 / 711]$ & 0.0005 \\
Potential early embryonic loss $^{\mathrm{d}}$ & $43.6[102 / 234]$ & $38.6[230 / 596]$ & 0.23 \\
Potential late embryonic loss $^{\mathrm{e}}$ & $13.1[18 / 137]$ & $7.7[30 / 387]$ & 0.08 \\
Cumulative pregnancy rate $^{\mathrm{f}}$ & $60.8[186 / 306]$ & $71.9[506 / 704]$ & 0.0005 \\
\hline
\end{tabular}

Source: (SILVA, A.G., 2021)

Notes: ${ }^{a}$ Number of cows with an active CL (>25\% of blood perfusion) on D14 over on the number of cows submitted to an ultrasound scanning at 14 days after TAI $(n=933)$. ${ }^{b}$ Number of cows with an active $\mathrm{CL}$ $(>25 \%)$ on Color-Doppler diagnosis at D22 over on the number of inseminated cows. ${ }^{\mathrm{C}}$ Number of cows with an viable embryo at D30-35 by B-mode ultrasonography over on the number of inseminated cows. ${ }^{\mathrm{d}}$ Number of cows without an active CL on D22 over on the number of cows with an active CL on D14. ${ }^{\mathrm{e}}$ Number of cows which an active CL on D22 but without an embryo on D30-35 over on the number of cows with an active CL on D22. ${ }^{\dagger}$ Number of cows pregnant after 2 TAls over on the number of cows inseminated in TAl 1 or TAI 2. Significant differences were declared at $P \leq 0.05$ and a tendency was declared when $P \leq 0.1$ and $P$ $>0.05$

$\mathrm{P} / \mathrm{Al}$ at resynchronization was $44.4 \%[216 / 486]$ and did not differ $(\mathrm{P}>0.1)$ between the EB treatment groups (Fig. 6). Also, the pregnancy rate at the second TAl was not affected $(P>0.1)$ by the BCS $(40 \%$ [67/169] for BCS <3; and $47 \%$ [149/317] for BCS $\geq 3$ ). The overall cumulative pregnancy rate (TAI 1 and TAI 2) was $68.5 \%(692 / 1010)$ and was affected by the treatment group and BCS $(P<0.05)$. The group effect represented a greater cumulative pregnancy rate in the EB-1 group than in the EB-2 group (Fig. 6). Regarding to BCS effect, cows with a BCS $\geq 3$ had greater cumulative pregnancy rate than $\mathrm{BCS}<3$ (Table 2). 
Figure 6 - P/Al 30-35 days after second TAl (\%) and cumulative P/Al [TAl $1+$ TAl 2] (\%) in EB-1 and EB-2 groups.

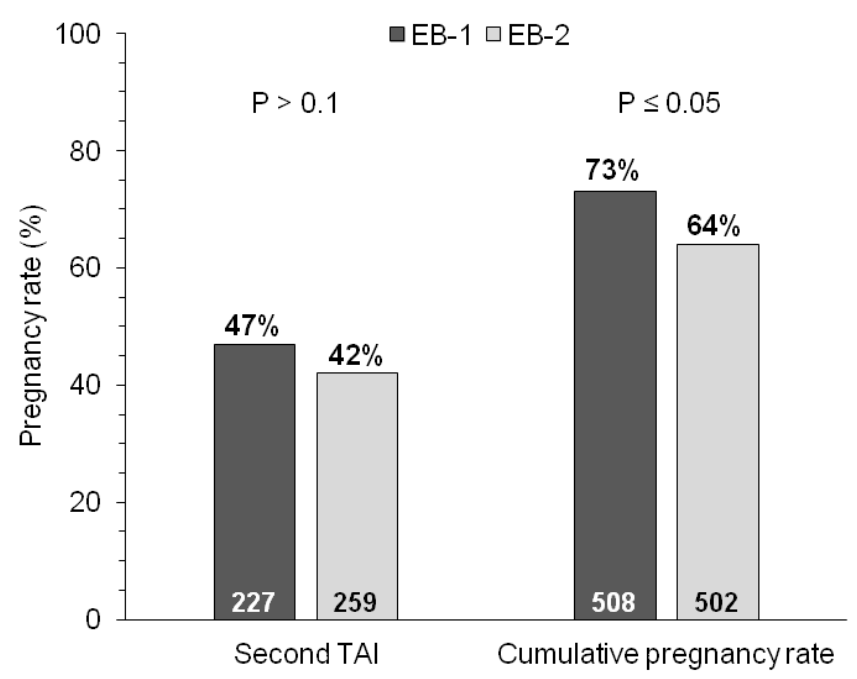

Source: (SILVA, A. G., 2021).

Note: Significant differences were declared at $P \leq 0.05$ and a tendency was declared when $P \leq 0.1$ and $\mathrm{P}>0.05$.

\subsubsection{Subgroup submitted to daily ultrasound scanning}

A new FWE was detected in 31 out of 37 cows enrolled in the daily scanning. The remaining cows (16.2\% [6/37]; five from the EB-1 group and one from the EB-2 group) were all pregnant females, which a FWE was not detected or the dominant follicle persisted until D22.

For the FWE data from D14 to D22 (Fig. 7), when all cows were considered regardless the pregnancy status, the proportion of cows with a detected FWE between D14 and D22 tended to be greater $(P=0.09)$ in the EB-2 group $(94.7 \%$ [18/19]) than in the EB-1 group (72\% [13/18]). Also, the proportion of cows with a synchronized FWE (from 3-5 days after treatment) tended to be greater $(P=0.06)$ in the EB-2 $(94.4 \%[17 / 18])$ than in the EB-1 group (61.5\% [8/13]). The day of a new FWE was earlier $(P<0.05)$ in the cows of EB-1 (day $17.2 \pm 0.5)$ than EB-2 (day 18.2 
$\pm 0.2)$ group. A difference in dispersion of the FWE between both groups was not detected $(P>0.1)$ by Bartlett's test (Fig.7).

Figure 7 - Individual values to day of follicular wave emergence (FWE) between EB-1 and EB-2 groups.

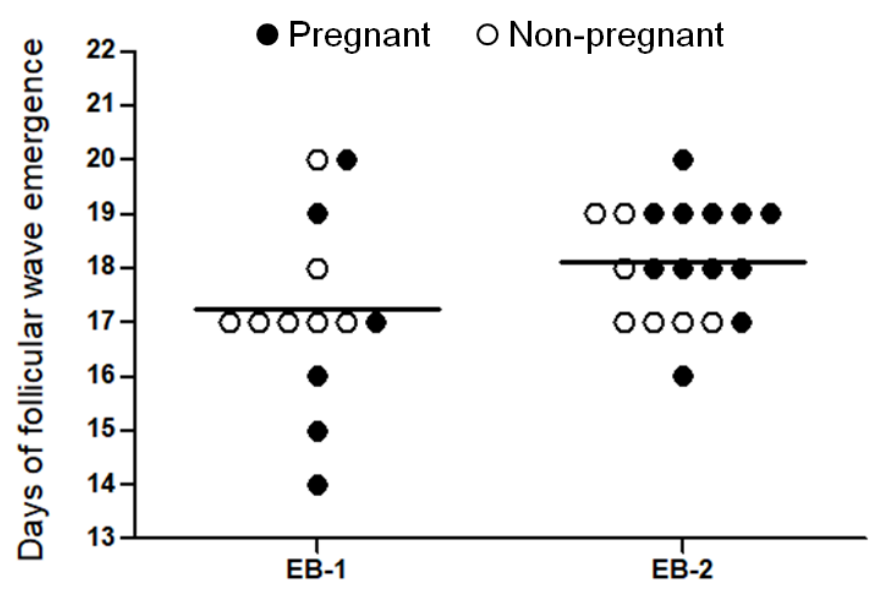

Source: (SILVA, A. G., 2021)

Notes: Individual values to day of follicular wave emergence in pregnant $(\bullet)$ and non-pregnant $(\circ)$ cows according to experimental groups. The horizontal bars represent the arithmetic mean for each treatment. The dispersion of the detected day of FWE did not differ among the treatment groups when analyzed by Bartlett's test $(P>0.1)$.

However, when the follicular characteristics were analyzed separately for nonpregnant animals, the proportion of cows with a FWE occurring between D14 and D22, and with a synchronized FWE (from 3-5 days after EB treatment) did not differ $(P>0.1)$ between groups (Table 3$)$. Regarding the follicle size and follicle growth rate in non-pregnant cows (Table 3), the mean diameter of the largest follicle on D22 and at TAI did not differ $(P>0.1)$ between EB-1 and EB-2 groups. Also, the growth rate (mm/day) of the largest follicle from FWE to the P4 device withdrawal (D22) did not differ $(P>0.1)$ between the groups. However, the largest follicle growth rate from $P 4$ device withdrawn (D22) to TAI (D24) was greater $(P<0.05)$ in the EB-1 than EB-2 group. Lastly, the growth rate of the largest follicle from FWE to TAI tended to be greater $(P=0.07)$ in the EB-1 than EB-2 group. The proportion of non-pregnant cows detected on D22 by Doppler ultrasonography that ovulated within $48 \mathrm{~h}$ after the second TAI did not differ $(P>0.1)$ between EB-1 and EB-2 groups (Table 3). 
Table 3. Ovarian characteristics in non-pregnant cows resynchronized with 1 or $2 \mathrm{mg}$ EB associated to a P4 device at 14 days post-TAl.

\begin{tabular}{|c|c|c|c|}
\hline End point & $E B-1[n=7]$ & $\mathrm{EB}-2[\mathrm{n}=7]$ & $P$ value \\
\hline Proportion of cows with a detected FWE, $\%^{a}$ & $100[7 / 7]$ & $100[7 / 7]$ & 1 \\
\hline Proportion of cows with a synchronized FWE, $\%^{b}$ & $86[6 / 7]$ & $100[7 / 7]$ & 1 \\
\hline Follicular wave emergence, days ${ }^{c}$ & $17.6 \pm 0.4$ & $17.7 \pm 0.4$ & 0.67 \\
\hline Structural luteolysis, days ${ }^{d}$ & $20.6 \pm 0.4$ & $19.3 \pm 0.4$ & 0.04 \\
\hline \multicolumn{4}{|l|}{ Size of largest follicle, $\mathrm{mm}^{\mathrm{e}}$} \\
\hline On D22 & $12 \pm 1.0$ & $11.5 \pm 1.0$ & 0.8 \\
\hline On D24 & $15.1 \pm 1.0$ & $13.4 \pm 1.0$ & 0.2 \\
\hline \multicolumn{4}{|l|}{ Growth rate of largest follicle, $\mathrm{mm} / \mathrm{day}$} \\
\hline Emergence to D22 & $1.6 \pm 0.1$ & $1.6 \pm 0.1$ & 0.7 \\
\hline D22 to D24 & $1.6 \pm 0.2$ & $0.9 \pm 0.1$ & 0.03 \\
\hline Emergence to D24 & $1.6 \pm 0.3$ & $1.4 \pm 0.1$ & 0.07 \\
\hline Proportion of cows ovulated $48 \mathrm{~h}$ after TAl, $\%^{f}$ & $100[7 / 7]$ & $100[7 / 7]$ & 1 \\
\hline
\end{tabular}

Source: (SILVA, A. G., 2021)

Notes: " Cows with a detected new FWE during the protocol period ${ }^{\mathrm{b}}$ Cows with a detected new FWE occurring between 3 to 5 days after the treatment (D17-19); ${ }^{\circ}$ Defined by means of a retrospective evaluation, when the dominant follicle first appeared between 4 and $5 \mathrm{~mm} ;{ }^{d}$ Defined by a retrospective evaluation as the day when the $C L$ presented for the first time a blood perfusion $\leq 25 \%$; ${ }^{e}$ Measured by taking the mean of the maximum length and width using the caliper function; ${ }^{\dagger}$ Was confirmed by disappearance of largest follicle at the ultrasonographic exam $48 \mathrm{~h}$ after TAl.

The time of structural luteolysis in EB-2 group was anticipated $(P<0.05)$ when compared to the EB-1 group (Table 3). When the data of area and blood perfusion of CL were analyzed over D14 to D22 (Fig. 8), only a significant $(P<0.05)$ interaction of pregnancy status by time was observed for both characteristics. For non-pregnant cows, as expected, the CL area and blood perfusion decreased progressively from D18 to D22, regardless treatment group. For pregnant cows, the CL area and blood perfusion did not differ $(P>0.1)$ over the $D 14$ to $D 22$. Although a significant interaction of treatment group by pregnancy status or a triple interaction treatment group by pregnancy status by time were not detected, the effect of treatment group was also evaluated separately in a post-hoc analysis for pregnant and non-pregnant cows. A significant effect of treatment group or interaction of treatment group by time were also not detected for both CL characteristics. 
Figure 8 - Mean \pm SEM CL area $\left(\mathrm{cm}^{2}\right)$ and blood perfusion in beef cows submitted to a resynchronization of ovulation program 14 days after TAl.



Source: (SILVA, A. G., 2021)

Notes: Mean \pm SEM CL area $\left(\mathrm{cm}^{2}\right)$ and blood perfusion in pregnant $(\mathrm{n}=19)$ and non-pregnant $(\mathrm{n}=$ 14) beef cows submitted to resynchronization protocol at 14 days after TAl. The interaction of pregnancy status by time (PS*t) is indicated. Data from D14 was used as a covariate. The asterisk ( $\left.{ }^{*}\right)$ indicates differences $(P \leq 0.05)$ between pregnancy status from D18 to D22.

\subsection{DISCUSSION}

A dose of $1 \mathrm{mg}$ EB associated with an intravaginal P4 device on D13 or 14 post-TAl is sufficient to synchronize the FWE in heifers (MOTTA et al., 2020) and is not a risk to disturb a pre-existing pregnancy in beef cattle (MOTTA et al., 2020; PALHÃO et al., 2020). In dairy cattle, lactating cows had a greater basal liver blood flow than non-lactating cows. This high liver blood flow in lactating cows was probably to chronic effects of a high nutritional plane.(SANGSRITAVONG et al., 2002), Furthermore, beef cows are heavier than beef heifers (DISKIN; KENNY, 2014). Therefore, due to these two factors, the use of $2 \mathrm{mg} \mathrm{EB}$ is recommended for synchronization of FWE in cows (BÓ et al., 2002; PESSOA et al., 2015). However, the effects of $2 \mathrm{mg}$ EB treatment administered close to the period of maternal recognition of pregnancy on FWE and establishment of pre-existing pregnancy in suckled Bos indicus cows are not known. Therefore, we compared in the present study the use of 1 or $2 \mathrm{mg} \mathrm{EB}$ at the beginning of a resynchronization protocol at 14 
days post-TAI in suckled Nelore cows, and the results indicated that $1 \mathrm{mg}$ EB is safer and results in satisfactory pregnancy rates in the resynchronized cows.

The first important factor for developing a hormonal protocol for resynchronization of ovulation is that the treatments need to be efficient to induce follicle turnover and a new synchronized FWE for a second TAI. Our hypothesis that the $2 \mathrm{mg}$ EB induces a more synchronized FWE than $1 \mathrm{mg}$ was partially supported. The suckled cows treated with $2 \mathrm{mg}$ EB presented later FWE and a greater proportion of synchronized FWE (3-5 days after treatment), regardless the pregnancy status; whereas, when the characteristics of FWE (mean day, dispersion and proportion of cows with a synchronized FWE) were analyzed separately only in nonpregnant animals, no difference between 1 and 2 mg EB was observed. To our knowledge, the comparison of 1 vs. $2 \mathrm{mg}$ EB have not been reported in suckled beef cows for resynchronization of ovulation at the second week after TAl. Nonetheless, Pessoa et al. (2015) reported that suckled Nelore cows receiving 2 mg EB on day 22 after TAI have lesser dispersion of FWE and greater pregnancy rate at resynchronization than their counterparts receiving $1 \mathrm{mg}$ EB. This difference between studies could be associated with the different moments when the resynchronization protocol started. The herein resynchronization program started in the middle-late diestrus, when almost $90 \%$ of the cows had an active CL secreting P4. The resynchronization program carried out by Pessoa et al. (2015), starts on day 22 after TAl, when is expected the greatest proportion of non-pregnant cows at pro-estrus, estrus or metestrus stages (FORDE et al., 2011; PUGLIESI et al., 2014; FERNANDES et al., 2021). In addition, in our preliminary study (Chapter 1; Silva et al., 2021), no difference was observed in FWE among suckled Nelore cows treated with 1, 1.5 or $2 \mathrm{mg}$ EB associated to a P4 device at the beginning of synchronization 
protocol in a random day of estrous cycle. Burke et al. (2000), demonstrated in nonlactating Holstein cows that the administration of $1 \mathrm{mg}$ EB associated with a P4 device on day 13 of the estrous cycle induces follicle turnover of the dominant second wave follicle, regardless of the follicle size. Corroborating with the outcomes of our study, early studies indicate that the administration of $1 \mathrm{mg}$ EB in lactating dairy cows on days 12,13 or 14 after insemination induces a new FWE 4 to 5 days after EB treatment (MACMILLAN; TAUFA; DAY, 1997). All together, these results support that $1 \mathrm{mg}$ EB could be also efficient for synchronization of FWE in beef animals.

Besides the effects on follicle dynamics, for resynchronization of ovulation in a period when the pregnancy status from previous TAl is not known, treatments should also not be harmful to $\mathrm{CL}$ function and pregnancy establishment. Although the association of P4 and E2 esters is commonly used in TAl protocols, luteolysis is induced by E2 or E2 esters treatments after 10 to 14 days of P4 exposure in nonpregnant heifers (ARAUJO et al., 2009; PUGLIESI et al., 2011; 2012). Pugliesi et al. (2011) reported that the prominence of $\mathrm{PGF}_{2 \alpha}$ pulses, the luteolytic agent, increases with increasing dose of $17-\beta$ E2 $(0.01,0.05$ and $1 \mathrm{mg})$ on day 14 after ovulation in Holstein heifers. In our study, luteolysis occurred about 1 day earlier in the group of cows treated with $2 \mathrm{mg}$ EB compared to the group treated with $1 \mathrm{mg}$ EB. The mechanisms involved in this anticipation are expected to be related to the uterine expression of receptors for E2 (ESR) and oxytocin (OXTR), which are fundamental for triggering luteolysis in cattle. At late diestrus, P4 downregulates the expression of its own receptors (MCCRACKEN; CUSTER; LAMSA, 1999). This allows for increase in ESR and OXTR synthesis. In a regular estrous cycle, the increase in OXTR expression is facilitated by elevated circulating E2 concentrations, coming from the 
follicles, and reduced P4 concentrations. Finally, the pulsatile secretion of OXT by neurohypophysis and corpus luteum associated to the increased expression of OXTR leads to release of luteolytic pulses of PGF $2 a$ (MCCRACKEN; CUSTER; LAMSA, 1999). Similarly, treatments with 1 or $5 \mathrm{mg} 17-\beta$ E2 on day 15 of the estrous cycle in Nelore females up-regulates the transcription of OXTR between 3 and 4 hours after treatment (FELTRIN, 2020; OLIVEIRA et al., 2021). Motta et al. (2020) also reported that luteolysis was anticipated in resynchronized non-pregnant heifers receiving $1 \mathrm{mg} 17-\beta$ E2 or EB 14 days after TAl compared to the control group, which received only a single intravaginal $\mathrm{P} 4$ device. Therefore, our running hypothesis is that the expected increase in circulating $\mathrm{E} 2$ when cows received $2 \mathrm{mg}$ EB results in a rapid upregulation of OXTR expression, leading the anticipation of luteolysis.

Although the $\mathrm{E} 2$ role in triggering luteolysis is known, our expectation was that the interferon-tau (IFNT) from conceptus will prevent expression of endometrial receptors (ESR and OXTR), inhibiting the E2-induced pulsatile secretion of $\mathrm{PGF}_{2 \alpha}$ and allowing pregnancy establishment in EB-treated pregnant cows (SPENCER et al., 2007; ROCHA et al., 2021). However, the hypothesis that the pregnancy establishment from the first TAI is not impacted by increasing the EB dose from 1 to 2 $\mathrm{mg}$ was not supported. We observed for the first time that $2 \mathrm{mg}$ EB when administered associated to an intravaginal P4 device at day 14 post-TAl results in negative effects in pregnancy establishment from first TAI. That is, cows receiving 2 mg EB compared to $1 \mathrm{mg}$ EB had lesser pregnancy rates, and greater potential pregnancy loss after first TAl. Although the endometrial secretion of PGF $2 \alpha$ was not determined in the present study, the negative effects of $2 \mathrm{mg}$ EB on pregnancy maintenance may be partially related to induction of endometrial release of sequential luteolytic $\mathrm{PGF}_{2 \alpha}$ pulses. In this regard, our group recently reported 
(MOTTA et al., 2021) that treatment with $1 \mathrm{mg}$ E2 for resynchronization at day 14 after TAl induces pulses of $\mathrm{PGF}_{2 \alpha}$ in pregnant heifers; however, more studies are needed to assess the effect of different EB doses on the endometrial receptors and $\mathrm{PGF}_{2 \alpha}$ release in pregnant animals.

Interestingly, the greatest negative effect that supports that $2 \mathrm{mg}$ EB is not indicated to resynchronize beef cows 14 days after TAI was the potential embryonic loss rate between D22 and D30-35. This rate was doubled in cows treated with $2 \mathrm{mg}$ EB; whereas, based on presence of an active CL, a lesser impact (23.7\% increase) was observed for the potential early embryonic loss between D14 and D22. This finding is a further indication that elevated E2 concentrations negatively impact pregnancy during the third week of gestation, but its major effect is probably on the subsequent embryo development and maintenance (from 22 to 30-35 days of pregnancy). We postulate that two factors may be associated in causing this greater potential late embryonic loss in cows receiving $2 \mathrm{mg}$ EB. Firstly, the luteolysis may have been postponed by either the P4 device maintenance until D22 or by the conceptus-induced changes in the uterus previously to embryo loss. In this regard, elevated P4 concentrations inhibit LH pulsatility, therefore, there is a smaller follicular diameter and, consequently, a lesser E2 production/secretion by the follicle (BATISTA et al., 2017; DIAS et al., 2021). Also, embryo recipient cows resynchronized with two intravaginal P4 devices 13 days post-estrus had a smaller dominant follicle and lesser proportion luteolysis detection on day 22 than cows resynchronized with a single P4 device (ATAÍDE et al., 2018). Then, when the P4 devices is removed on D22 in the present study, the secretion of E2 by the dominant follicle may has increased and induced luteolysis. Regarding the long-term effects of conceptus on $\mathrm{CL}$, pregnancy losses occurring on day 16 or after may prolong the 
luteal phase (NORTHEY; FRENCH, 1980; WILTBANK et al., 2016). Alternatively, our second postulation is that the $2 \mathrm{mg}$ EB treatment may have directly impaired the conceptus development, which did not modify it signaling (IFNT secretion) for maintenance of $\mathrm{CL}$, but impact on trophectoderm for adequate placentation process. Further investigations are needed to unravel the E2 actions during the third week of pregnancy, and whether it has a direct effect on the conceptus, CL or even on uterine environment.

Based on the present and previous studies also using EB doses greater than 1 mg (COLAZO et al., 2006; MACHADO et al., 2008; VIEIRA et al., 2014), is suggested that a dose-dependent effect of EB treatment on pregnancy established occurs. Also, the EB treatment in the period prior to maternal recognition of pregnancy seem to be influenced by factors such as timing of treatment, parity order, and metabolic status (CUTAIA et al., 2002; EL-ZARKOUNY; STEVENSON, 2004; VIEIRA et al., 2014; MOTTA et al., 2020). There is consistency in previous studies that using $1 \mathrm{mg}$ EB associated with an intravaginal P4 device on days 12, 13 or 14 after TAl there was no harmful effect to the pregnancy established from first TAI (MACMILLAN; TAUFA; DAY, 1997; CUTAIA et al., 2002; EL-ZARKOUNY; STEVENSON, 2004; MOTTA et al., 2020; PALHÃO et al., 2020; VIEIRA et al., 2021). On the other hand, when a 50\% higher dose $(1.5 \mathrm{mg})$ of EB (VIEIRA et al., 2014) or 17ß-E2 (COLAZO et al., 2006) was used associated with a P4 device, authors reported controversial effects on the pregnancy of dairy cows and beef heifers. In dairy cows, the pregnancy rate from first TAl was lower in the group resynchronized with $1.5 \mathrm{mg}$ EB plus a P4 device $(14.9 \%$ [13/87]) than in the control group (32.6\% [28/86]). Harmful effects on pregnancy were also reported by Machado et al. (2008); however, a dose of $5 \mathrm{mg} 17 \beta$-E2 on day 12 after TAI was used. In beef heifers, Colazo et al. (2006) reported that the pregnancy 
rate from first TAI did not differ between the control group (47.3\% [44/93]) and the group of cows receiving $1.5 \mathrm{mg} 17 \beta-\mathrm{E} 2$ associated with a P4 device and $50 \mathrm{mg}$ of injectable P4 (49.5\% [46/93]). Also contrary to the results in our study, Elliff et al. (2019) in a study with a limited number of animals, reported that there was no difference in the pregnancy rate of Nelore cows resynchronized on day 14 after TAI with $2 \mathrm{mg} \mathrm{EB}+100 \mathrm{mg}$ iP4 or with $100 \mathrm{mg}$ iP4 associated with a P4 device. Therefore, a possible factor associated with these contradictory effects on pregnancy establishment is the ratio between circulating E2 and P4 concentrations (E2:P4) at the beginning of resynchronization program. Studies which in addition to E2 treatment, the P4 was administered, the effects of P4 may overcome the EB effects on endometrial factors involved in triggering luteolysis, but this hypothesis needs further investigation. Another factor that may have contributed to an increased between circulating E2:P4 was the use of devices previously used for 8 or 16 days in our study. Lower circulating P4 concentrations are observed when using previously used P4 devices compared to new devices (SALES et al., 2015). Therefore, a greater E2:P4 at the beginning of resynchronization when using $2 \mathrm{mg}$ EB and a used P4 device may have up regulated the ESR and OXTR in the uterus, leading to induction of luteolysis in part of pregnant animals.

The third hypothesis that cows receiving $2 \mathrm{mg}$ EB would have a greater pregnancy rate at resynchronization was not supported. Pregnancy rate at the second TAI was not affected by the EB dose. In this regard, Palhão et al. (2020), using $1 \mathrm{mg}$ EB associated to a P4 device 13 days after TAl reported pregnancy rates in suckled beef cows submitted to the second TAl similar (42.8\%) to those observed in our study (47\%). Unexpectedly, in our first experiment, follicular growth rate between D22 and D24 were greater for cows receiving $1 \mathrm{mg}$ EB compared to $2 \mathrm{mg}$. 
Also, growth rate from FWE to D24 tended to be greater in cows receiving $1 \mathrm{mg}$ EB. However, in the Experiment 2, where a large number of animals were evaluated, these differences between EB doses were not sustained. Therefore, when the P4 concentrations are elevated as at the beginning of resynchronization at D14 after TAl, both 1 or $2 \mathrm{mg}$ EB induce the emergence of a new synchronized follicular wave and a dominant follicle of similar size. This reflected in a similar pregnancy rate at resynchronization started 14 days after TAI in suckled Nelore cows. Therefore, the present and previous results from Palhão et al. (2020) support a high effectiveness of using $1 \mathrm{mg}$ EB for starting resynchronization 13 or 14 days after TAI.

Also, it is knowledge that greater pregnancy rates at the beginning of the breeding season impact both subsequent maternal reproductive performance and the productive performance of calves (SÁ FILHO et al., 2013; BARUSELLI et al., 2017). In this regard, Ojeda et al. (2021) compared different types of resynchronization strategies and reported that when performing two TAls within an interval of 24 days it is possible to reach $75 \%$ of pregnancy rate and this represents the reproductive program with the best technical performance. In our study, after two TAls with an interval of 24 days, the cumulative pregnancy rate (TAI $1+$ TAl 2) was close to that indicated by Ojeda et al. (2021) only when cows received $1 \mathrm{mg}$ EB (73\%). The negative effects of increasing the EB from 1 to $2 \mathrm{mg}$ on establishment of the preexisting pregnancy associated with the no improvement of the pregnancy rate at the second TAl contributed to a lesser cumulative pregnancy rate (64\%) in cows receiving $2 \mathrm{mg}$ EB. Therefore, for an efficient reproductive performance in suckled beef cows submitted to two TAls within 24 days, $1 \mathrm{mg}$ EB is the recommended dose for beginning of resynchronization. 
Lastly, the impact of BCS has on fertility in cows is well known. In our study, although the interaction between BCS and treatment was not observed, significant effects of BCS were observed in several overcomes from first TAI. Proportion of cows bearing an active $\mathrm{CL}$ at D14 or D22 and pregnancy rates at D30-35, as well as cumulative pregnancy rate were decreased in cows with $\mathrm{BCS}<3$ than those with BCS $\geq 3$ (in a BCS scale from 1 to 5 ). More interestingly, the reduction in these fertility outcomes in cows with BCS $<3$ increases progressively at the time points evaluated during early pregnancy. This was indicated by $10 \%, 20 \%$ and $25 \%$ reduction, respectively, for proportion of CL on D14 and D22, and pregnancy rate at D30-35 in cows with BCS $<3$. The present novel results of proportion of active CL on D14 after TAI indicated that an important cause of lesser pregnancy rate in cows with low BCS $(<3)$ is a lower ovulation rate at the first synchronization. This result is probably a consequence of reduced LH support during dominant follicle growth and reduced pre-ovulatory follicle in cows with low BCS (NISHIMURA et al., 2018). Cows with adequate BCS ovulate larger follicles with greater E2 concentrations, which in turn, better modulate the uterine environment and results in better quality CL that produce a greater P4 concentrations, contributing to a greater pregnancy rate (BINELLI et al., 2014; SALES et al., 2015; NORONHA et al., 2020). In addition to impairing the ovulation response in TAI protocols, potential embryonic loss tended to be greater in cows with $\mathrm{BCS}<3$, indicating that BCS also impact the pregnancy maintenance of animals from first TAI. Therefore, the present results indicate that the lower pregnancy rate often observed in animals with BCS $<3$ is caused by an association of reduced ovulation rate in response to TAl protocol and an increase in early pregnancy loss, mainly after the period when placentation process starts. 


\subsection{CONCLUSIONS}

In conclusion, the use of 1 or $2 \mathrm{mg} \mathrm{EB}$ is efficient in promoting a new FWE when the circulating concentrations of P4 are elevated. The decreased pregnancy rate from first TAl observed in the group of cows receiving $2 \mathrm{mg}$ indicates that this dose is not recommended for use close to maternal recognition of pregnancy, as in resynchronization programs initiated 14 days after TAI. Considering the satisfactory pregnancy rates in the first and second TAls, the use of $1 \mathrm{mg}$ EB associated with a P4 device provides an elevated cumulative pregnancy rate after two TAls with an interval of 24 days. Furthermore, suckled beef cows with a low body condition (BCS <3) have a decreased ovulation response to the first TAl and tend to have an increased potential late embryonic loss, which result in lesser pregnancy rate compared to cows with BCS $\geq 3$.

\section{FINAL CONSIDERATIONS}

Synchronization and resynchronization protocols based on the association between E2 and P4 are widely used in beef farms with high use of reproductive biotechnologies. Thus, the two studies that make up this dissertation showed the efficiency of EB in promoting follicular turnover and synchronization of a new FWE. To evaluate the effect of different EB doses in the first postpartum synchronization, we carried out a preliminary experiment with a reduced number of animals. This primary data obtained encourage us to investigate more about the effect of EB doses on the fertility of animals and also about the effect that the parity order has on the response to estrus synchronization and ovulation protocols for TAl. Therefore, given the scarcity of studies evaluating different EB doses in synchronization protocols in suckled Bos indicus cows, our study, provides support for further research on 
adjustments to synchronization protocols in this genetic group widely spread in our country as well as Nelore breed and its crosses.

Regarding the initiation of resynchronization of ovulation close to the period of maternal recognition of pregnancy, it is not a new strategy. However, initial studies since the 90's were based on the return to estrus to identify non-pregnant cows. More recently, with the possibility of detecting luteolysis through color-Doppler ultrasonography with high accuracy between days 20-22 post-TAl, there has been an intensification of studies on resynchronization at the second week of gestation. Based on the results of the study, which was the first to compare EB doses in the period close to maternal recognition of pregnancy, we were able to answer which dose is indicated for resynchronization protocols started at 14 days after TAl in suckled Bos indicus beef cows. However, a wide range was opened for us to study the physiological processes involved in the dose-dependent effect observed in our study. Thus, it will be possible to unravel the physiological processes involved in triggering the release of $\mathrm{PGF}_{2 \alpha}$ induced by estradiol during the critical period in pregnant animals and the dynamics of the expression of endometrial ESR and OXTR. In addition, the effect of estradiol on conceptus development during the second and third weeks of gestation is still unknown.

As indicated by previous studies, the response E2 treatment close to the recognition maternal of pregnancy appears to be influenced by several factors such as genetic group, parity order, metabolic status and timing of administration. In view of this, the dose comparison can also be explored considering these factors and the effects in dairy cattle. Furthermore, as indicated in the herein study, the use of previously used P4 devices may have contributed to a greater E2:P4 ratio, leading to a rapid increase in endometrial ESR and OXTR. Thus, it is also necessary to 
consider the possibility of providing greater P4 concentrations through inserting devices releasing greater $\mathrm{P} 4$ amounts in circulation, which will reduce the E2:P4 ratio. Also in this context, we can consider other estradiol esters to synchronize FWE, which do not induce an elevated E2 peak in circulation, such as estradiol valerate. 


\section{REFERENCES}

ALVES, R. L. O. R. et al. Hormonal combinations aiming to improve reproductive outcomes of Bos indicus cows submitted to estradiol/progesterone-based timed $\mathrm{Al}$ protocols. Theriogenology, v. 169, p. 89-99, 2021.

ARAUJO, R. R. et al. Role of follicular estradiol-17beta in timing of luteolysis in heifers. Biology of Reproduction, v. 81, n. 2, p. 426-437, 2009.

ASSOCIAÇÃO BRASILEIRA DAS INDÚSTRIAS EXPORTADORAS DE CARNES [ABIEC]. Beef Report: Perfil da pecuária no Brasil. BeefREPORT, p. 60, 2021. Disponível em: <http://abiec.com.br/publicacoes/beef-report-2021/>.

ATAÍDE, G. A. et al. Eficácia da Ultrassonografia Doppler para detecção de não prenhez em vacas de corte receptoras. In: Anais da XXXII Reunião Anual da Sociedade Brasileira de Tecnologia de Embriões; 2018 Aug 16-19; Santa Catarina, Florianópolis. Santa Catarina: SBTE; 2018. p.177-178.

AYRES, $\mathrm{H}$. et al. Validation of body condition score as a predictor of subcutaneous fat in Nelore (Bos indicus) cows. Livestock Science, v. 123, n. 2-3, p. 175-179, 2009. Disponível em: <http://dx.doi.org/10.1016/j.livsci.2008.11.004>.

BARUSELLI, P. et al. History, evolution and perspect ives of timed artificial in semination programs in Brazil. Animal Reproduction, v. 9, n. 3, p. 139-152, 2012.

BARUSELLI, P. S. et al. Timed artificial insemination: Current challenges and recent advances in reproductive efficiency in beef and dairy herds in Brazil. Animal Reproduction, v. 14, n. 3, p. 558-571, 2017.

BARUSELLI, P. S.; ZANATTA, G. M.; ELLIFF, F. M. Novas tecnologias aplicadas ao manejo reprodutivo de vacas de cria. n. Gráfico 1, p. 26-34, 2018.

BASTOS, M. R. et al. Efeito da dose de benzoato de estradiol em associação à progesterona na sincronização da emergência da onda folicular em vacas Bos 
indicus e Bos taurus. In: Proceedings of the 25 th Annual Meeting of the Brazilian Embryo Technology Society; 2011 Aug 18-20; Ceará, Cumbuco. Ceará: SBTE; 2011. p. 376.

BATISTA, E. O. S. et al. The effect of circulating progesterone on magnitude of the $\mathrm{GnRH}$-induced LH surge: Are there any differences between Bos indicus and Bos taurus heifers? Theriogenology, v. 104, p. 43-48, 2017.

BINELLI, M. et al. Antiluteolytic strategies to improve fertility in cattle. Theriogenology, v. 56, n. January, p. 1451-1463, 2001.

BINELLI, M. et al. The role of proestrus on fertility and postovulatory uterine function in the cow. Animal Reproduction, v. 11, n. 3, p. 246-253, 2014.

BINELLI, M.; IBIAPINA, B. T.; BISINOTTO, R. S. Bases fisiológicas, farmacológicas e endócrinas dos tratamentos de sincronização do crescimento folicular e da ovulação. Acta sci vet, v. 34, n. Suplemento 1, p. 39-49, 2006.

BISINOTTO, R. S.; SANTOS, J. E. P. The use of endocrine treatments to improve pregnancy rates in cattle. Reproduction, Fertility and Development, v. 24, n. 1, p. 258-266, 2012.

BO, G. A. et al. Ovarian follicular wave emergence after treatment with progestogen and estradiol in cattle. Animal Reproduction Science, v. 39, n. 3, p. 193-204, 1995.

BÓ, G. A. et al. The control of follicular wave development for self-appointed embryo transfer programs in cattle. Theriogenology, n. 01, p. 93, 2002.

BÓ, G. A.; BARUSELLI, P. S.; MARTÍNEZ, M. F. Pattern and manipulation of follicular development in Bos indicus cattle. Animal Reproduction Science, v. 78, n. 3-4, p. 307-326, 2003.

BURKE, C. R. et al. Use of a small dose of estradiol benzoate during diestrus to synchronize development of the ovulatory follicle in cattle. Journal of Animal 
Science, v. 78, n. 1, p. 145-151, 2000.

BURKE, C. R. et al. Effects of maturity of the potential ovulatory follicle on induction of oestrus and ovulation in cattle with oestradiol benzoate. Animal Reproduction Science, v. 66, n. 3-4, p. 161-174, 2001.

BURKE, C. R. et al. Estradiol benzoate delays new follicular wave emergence in a dose-dependent manner after ablation of the dominant ovarian follicle in cattle. Theriogenology, v. 60, n. 4, p. 647-658, 2003.

CACCIA, M.; BÓ, G. A. Follicle wave emergence following treatment of cidr-b implanted beef cows with estradiol benzoate and progesterone. Theriogenology, $p$. 341, 1998.

CEPEA. 10 de Março de 2021 www.cnabrasil.org.br. 2021.

COLAZO, M. G. et al. Resynchronization of previously timed-inseminated beef heifers with progestins. Theriogenology, v. 65, n. 3, p. 557-572, 2006.

CREPALDI, G. A. . et al. Reproductive efficiency of Nelore cows submitted to three different reproductive strategies in a 64 days breeding season. Animal Reproduction, v. 14, n. 3, p. 698, 2017.

CUTAIA, L. et al. The use of estradiol and progesterone devices during mid-diestrus to synchronize return to estrus in beef cows and heifers. Theriogenology, p. 373, 2002.

DALMASO DE MELO, G. et al. Applied use of interferon-tau stimulated genes expression in polymorphonuclear cells to detect pregnancy compared to other early predictors in beef cattle. Theriogenology, v. 152, p. 94-105, 2020.

DIAS, H. P. et al. Progesterone dose during synchronization treatment alters luteinizing hormone receptor and steroidogenic enzyme mRNA abundances in granulosa cells of Nellore heifers. Animal Reproduction Science, v. 225, n. 
December 2020, p. 1-10, 2021.

DISKIN, M. G.; KENNY, D. A. Optimising reproductive performance of beef cows and replacement heifers. Animal, v. 8, n. SUPPL. 1, p. 27-39, 2014.

EL-ZARKOUNY, S. Z.; STEVENSON, J. S. Resynchronizing estrus with progesterone or progesterone plus estrogen in cows of unknown pregnancy status. Journal of Dairy Science, v. 87, n. 10, p. 3306-3321, 2004. Disponível em: <http://dx.doi.org/10.3168/jds.S0022-0302(04)73467-0>.

ELLIFF, F. et al. Using estradiol benzoate for resynchronization 14 days after timedai in nelore beef cows. In: International Animal Reproduction Symposium; 2019; Cordoba, Argentina: IRAC; 2019. p. 286, 2019.

FELTRIN, I. R. Efeitos do $17 \beta$-estradiol na abundância de transcritos para enzimas envolvidas na síntese de PGF2a endometrial em fêmeas bovinas no final do diestro. 87 p. 2020.

FERNANDES, C. A. C. et al. Timing of early resynchronization protocols affects subsequent pregnancy outcome in dairy cows. Theriogenology, v. 184, 2021.

FORDE, N. et al. Oestrous cycles in Bos taurus cattle. Animal Reproduction Science, v. 124, n. 3-4, p. 163-169, 2011. Disponível em: <http://dx.doi.org/10.1016/j.anireprosci.2010.08.025>.

GINTHER, O. J.; KNOPF, L.; KASTELIC, J. P. Temporal associations among ovarian events in cattle during oestrous cycles with two and three follicular waves. Journal of Reproduction and Fertility, v. 87, n. 1, p. 223-230, 1989.

KINDER, J. E. et al. Progestin and estrogen regulation of pulsatile LH release and development of persistent ovarian follicles in cattle The online version of this article , along with updated information and services, is located on the World Wide Web at: Progestin and Estr. Journal of Animal Science, p. 1424-1440, 1996. 
MACHADO, R. et al. Taxas de serviço, concepção e prenhez de vacas nelore tratadas com gonadotrofina coriônica humana e $17^{2}$-estradiol após a inseminação artificial em tempo fixo. Brazilian Journal of Veterinary Research and Animal Science, v. 45, n. 3, p. 221, 2008.

MACMILLAN, K. L.; TAUFA, V. K.; DAY, A. M. Manipulating ovaries' follicle wave patterns can partially synchronise returns to service and increases the pregnancy rate to second insemination. NZ Soc Anim Prod Proc, v. 57, p. 237-237, 1997.

MARTíNEZ, M. et al. 20 Effects of Dose of Estradiol Benzoate and Progesterone in Prostaglandin-Treated Beef Heifers. Reproduction, Fertility and Development, v. 17 , n. 2, p. 160, 2005a.

MARTÍNEZ, M. F. et al. Effects of oestradiol and some of its esters on gonadotrophin release and ovarian follicular dynamics in CIDR-treated beef cattle. Animal Reproduction Science, v. 86, n. 1-2, p. 37-52, 2005b.

MCCRACKEN, J. A. M. C.; CUSTER, E. E.; LAMSA, J. C. Luteolysis: A Neuroendocrine-Mediated Event. v. 79, n. 2, p. 263-324, 1999.

MEIKLE, A. et al. Effects of parity and body condition at parturition on endocrine and reproductive parameters of the cow. Reproduction, v. 127, n. 6, p. 727-737, 2004.

MOTTA, I. G. et al. Increased pregnancy rate in beef heifers resynchronized with estradiol at 14 days after TAI. Theriogenology, v. 147, p. 62-70, 2020. Disponível em: <https://doi.org/10.1016/j.theriogenology.2020.02.009>.

MOTTA, I. G. et al. Effects of estradiol treatments on PGF2 $\alpha$ release in beef heifers submitted to estrous resynchronization 14 days after timed-Al. Domestic Animal Endocrinology, v. 76, p. 106625, 2021. Disponível em: $<$ https://doi.org/10.1016/j.domaniend.2021.106625>.

National Academies of Sciences, Engineering, and Medicine. (2016). Nutrient requirements of beef cattle. 
NISHIMURA, T. K. et al. Importance of body condition score and ovarian activity on determining the fertility in beef cows supplemented with long-acting progesterone after timed-AI. Animal Reproduction Science, v. 198, 2018.

NORONHA, I. M. et al. Administering an additional prostaglandin F2 $\alpha$ injection to Bos indicus beef cows during a treatment regimen for fixed-time artificial insemination. Animal Reproduction Science, v. 219, n. April, p. 106535, 2020. Disponível em: <https://doi.org/10.1016/j.anireprosci.2020.106535>.

NORTHEY, D. L.; FRENCH, L. R. Effect of embryo removal and intrauterine infusion of embryonic homogenates on the lifespan of the bovine corpus luteum. Journal of animal science, v. 50, n. 2, p. 298-302, 1980.

OJEDA-ROJAS, O. A. et al. An agent-based simulation model to compare different reproductive strategies in cow-calf operations: Technical performance. Theriogenology, v. 160, p. 102-115, 2021.

OLIVEIRA, M. L. et al. Unravelling the role of $17 \beta$-estradiol on advancing uterine luteolytic cascade in cattle. Domestic Animal Endocrinology, v. 78, p. 106653, 2021. Disponível em: <https://doi.org/10.1016/j.domaniend.2021.106653>.

PALHÃO, M. P. et al. Early resynchronization of non-pregnant beef cows based in corpus luteum blood flow evaluation 21 days after Timed-Al. Theriogenology, v. 146, p. 26-30, 2020.

PESSOA, G. A. et al. Adjustment of the estradiol benzoate dose in the resynchronization protocol with unknown pregnancy status in suckled beef cows. In: Proceedings of the 29th Annual Meeting of the Brazilian EmbryoTechnology Society; 2015 Aug 20-23; Rio Grande do Sul, Gramado. Rio Grande do Sul: SBTE; 2015. p. 610.

PFEIFER, L. F. M. et al. Effect of injectable progesterone on follicular development in lactating beef cows treated with estradiol plus a low-concentration progesterone 
device. Brazilian Journal of Veterinary Research and Animal Science, v. 55, n. 2, p. 1-8, 2018.

PUGLIESI, G. et al. Effect of dose of estradiol-17ß on prominence of an induced 13,14-dihydro-15-keto-PGF2 $\alpha$ (PGFM) pulse and relationship of prominence to progesterone, LH, and luteal blood flow in heifers. Domestic Animal Endocrinology, v. 41, n. 2, p. 98-109, 2011. Disponível em: <http://dx.doi.org/10.1016/j.domaniend.2011.05.003>.

PUGLIESI, G. et al. Induction of PGFM pulses and luteolysis by sequential estradiol$17 \beta$ treatments in heifers. Theriogenology, v. 77, n. 3, p. 492-506, 2012. Disponível em: <http://dx.doi.org/10.1016/j.theriogenology.2011.08.020>.

PUGLIESI, G. et al. Conceptus-induced changes in the gene expression of blood immune cells and the ultrasound-accessed luteal function in beef cattle: How early can we detect pregnancy? Biology of Reproduction, v. 91, n. 4, p. 1-12, 2014.

PUGLIESI, G. et al. Improved fertility in suckled beef cows ovulating large follicles or supplemented with long-acting progesterone after timed-Al. Theriogenology, v. 85, n. 7, p. 1239-1248, 2016.

Disponível em: <http://dx.doi.org/10.1016/j.theriogenology.2015.12.006>.

PUGLIESI, G. et al. A novel strategy for resynchronization of ovulation in Nelore cows using injectable progesterone (P4) and P4 releasing devices to perform two timed inseminations within 22 days. Reproduction in Domestic Animals, v. 54, n. 8, p. 1149-1154, 2019.

ROCHA, C. C. et al. Ultrasonography-accessed luteal size endpoint that most closely associates with circulating progesterone during the estrous cycle and early pregnancy in beef cows. Animal Reproduction Science, v. 201, n. September, p. 12-21, 2019. Disponível em: <https://doi.org/10.1016/j.anireprosci.2018.12.003>.

ROCHA, C. C. et al. Conceptus-modulated innate immune function during early pregnancy in ruminants: A review. Animal Reproduction, v. 18, n. 1, p. 1-16, 2021. 
SA FILHO, M. F. et al. Effect of oestradiol valerate or benzoate on induction of a new follicular wave emergence in bos indicus cows and heifers treated with norgestomet auricular implant. Reproduction, Fertility and Development, v. 18, n. $2,2006$.

SÁ FILHO, M. F. et al. Ovarian follicle diameter at timed insemination and estrous response influence likelihood of ovulation and pregnancy after estrous synchronization with progesterone or progestin-based protocols in suckled Bos indicus cows. Animal Reproduction Science, v. 120, n. 1-4, p. 23-30, 2010. Disponível em: <http://dx.doi.org/10.1016/j.anireprosci.2010.03.007>.

SÁ FILHO, M. F. et al. Induction of ovarian follicular wave emergence and ovulation in progestin-based timed artificial insemination protocols for Bos indicus cattle. Animal Reproduction Science, v. 129, n. 3-4, p. 132-139, 2011.

SÁ FILHO, M. F. et al. Timed artificial insemination early in the breeding season improves the reproductive performance of suckled beef cows. Theriogenology, $v$. 79, n. 4, p. 625-632, 2013.

Disponível em: <http://dx.doi.org/10.1016/j.theriogenology.2012.11.016>.

SÁ FILHO, M. F. et al. Resynchronization with unknown pregnancy status using progestin-based timed artificial insemination protocol in beef cattle. Theriogenology, v. 81, n. 2, p. 284-290, 2014.

Disponível em: <http://dx.doi.org/10.1016/j.theriogenology.2013.09.027>.

SÁ FILHO, O. J. et al. Fixed-time artificial insemination with estradiol and progesterone for Bos indicus cows II: Strategies and factors affecting fertility. Theriogenology, v. 72, n. 2, p. 210-218, 2009.

SALES, J. N. S. et al. Effect of circulating progesterone concentration during synchronization for fixed-time artificial insemination on ovulation and fertility in Bos indicus (Nelore) beef cows. Theriogenology, v. 83, n. 6, p. 1093-1100, 2015. Disponível em: <http://dx.doi.org/10.1016/j.theriogenology.2014.12.009>. 
SALES, J. N. S. et al. Effects of eCG are more pronounced in primiparous than multiparous Bos indicus cows submitted to a timed artificial insemination protocol. Theriogenology, v. 86, n. 9, p. 2290-2295, 2016. Disponível em: <http://dx.doi.org/10.1016/j.theriogenology.2016.07.023>.

SANGSRITAVONG, S. et al. High feed intake increases liver blood flow and metabolism of progesterone and estradiol-17 $\beta$ in dairy cattle. Journal of Dairy Science, v. 85 , n. 11, p. 2831-2842, 2002. Disponível em: <http://dx.doi.org/10.3168/jds.S0022-0302(02)74370-1>.

SARTORI, R.; MONTEIRO, P. L. J.; WILTBANK, M. C. Endocrine and metabolic differences between Bos taurus and Bos indicus cows and implications for reproductive management. Animal Reproduction, v. 13, n. 3, p. 168-181, 2016.

SILVA, A. G. et al. Dose - dependent effects of estradiol benzoate for resynchronization of ovulation at 14 days after timed artificial insemination in beef cows. Animal reproduction (Abstract), v. 17, n. 3, 2020.

SIQUEIRA, L. G. B. et al. Color Doppler flow imaging for the early detection of nonpregnant cattle at 20 days after timed artificial insemination. Journal of Dairy Science, v. 96, n. 10, p. 6461-6472, 2013. Disponível em: <http://dx.doi.org/10.3168/jds.2013-6814>.

SPENCER, T. E. et al. Pregnancy recognition and conceptus implantation in domestic ruminants: Roles of progesterone, interferons and endogenous retroviruses. Reproduction, Fertility and Development, v. 19, n. 1, p. 65-78, 2007.

UNGERFELD, R. et al. Behavioral and physiological changes in early-weaned multiparous and primiparous beef cows. Animal, v. 5, n. 8, p. 1270-1275, 2011.

VIEIRA, A. et al. Factors affecting the reproductive performance of nellore cows on the cerrado conditions of central Brazil. Revista Brasileira de Zootecnia, v. 34, n. 6 SUPPL., p. 2408-2416, 2005. 
VIEIRA, C. C. et al. Resynchronization of follicular wave using long-acting injectable progesterone or estradiol benzoate at 14 days post-TAl in Bos taurus $\mathrm{x}$ Bos indicus beef heifers. Theriogenology, $2021 . \quad$ Disponível em: <https://doi.org/10.1016/j.theriogenology.2021.09.017>.

VIEIRA, L. M. et al. Resynchronization in dairy cows 13 days after TAl followed by pregnancy diagnosis based on corpus luteum vascularization by color doppler. Animal Reproduction, v. 11, n. 3, p. 378 (abstract), 2014.

WILTBANK, M. C. et al. Pivotal periods for pregnancy loss during the first trimester of gestation in lactating dairy cows. Theriogenology, v. 86, n. 1, p. 239-253, 2016. Disponível em: <http://dx.doi.org/10.1016/j.theriogenology.2016.04.037>. 
ATTACHMENT A - Proof of submission of the manuscript in the journal Animal Reproduction

Animal Reproduction

\section{CS.d Animal Reproduction}

Comparison of three doses of estradiol benzoate for synchronization of follicular wave emergence in suckled Bos indicus beef cows

\begin{tabular}{|r|l|}
\hline Journal: & Animal Reproduction \\
\hline Manuscript ID & AR-2021-0016.R2 \\
\hline Manuscript Type: & Short Communication \\
\hline Author: & 27-Junn-2021 \\
\hline Complete List of Authors: & $\begin{array}{l}\text { Guimarães SIlva, Amanda; Department of Animal Reproduction, School } \\
\text { of Veterinary Medicine and Animal Science, University of Sao Paulo, } \\
\text { Pirassununga, São Paulo, Brazil } \\
\text { Pinto, Leonardo; Department of Animal Reproduction, School of } \\
\text { Veterinary Medicine and Animal Science, University of Sao Paulo, } \\
\text { Pirassununga, São Paulo, Brazil } \\
\text { Amorim Silva, Nadark; Department of Animal Reproduction, School of } \\
\text { Veterinary Medicine and Animal Science, University of Sao Paulo, } \\
\text { Pirassununga, São Paulo, Brazil } \\
\text { Degan Mattos, Ana Clara; School of Agricultural and Veterinarian } \\
\text { Sciences, São Paulo State University (Unesp), Jaboticabal, SP, Brazil } \\
\text { Ambrósio, Pablo; Department of Animal Reproduction, School of } \\
\text { Veterinary Medicine and Animal Science, University of Sao Paulo, } \\
\text { Pirassununga, São Paulo, Brazil } \\
\text { Roncato Duarte, Keila; Säo Paulo Agribusiness Technology Agency (Tietê } \\
\text { Research and Development Unit), Tietê - SP, Brazil } \\
\text { Herrera Alvarez, Rafael; Säo Paulo Agribusiness Technology Agency } \\
\text { (Tietê Research and Development Unit), Tietê - SP, Brazil } \\
\text { Pugliesi, Guilherme ; Universidade de São Paulo, Department of Animal } \\
\text { Reproduction; }\end{array}$ \\
\hline Keyword: & \begin{tabular}{l} 
Bos indicus, cattle, estradiol benzoate, follicular dynamics, pluriparous \\
\hline
\end{tabular} \\
\hline
\end{tabular}

SCHOLARONE ${ }^{m}$

Manuscripts 